\title{
Türk Basınında Makbul Vatandașlık Kurgusu: Hürriyet ve Cumhuriyet Gazetelerinin Haber Söylemleri Üzerine Bir İnceleme ${ }^{1}$
}

\author{
Didem Deniz Anamur²
}

\begin{abstract}
Öz
$\mathrm{Bu}$ makale "makbul vatandaş"lığın zaman içerisinde nasıl kodlandığını anlamaya çalışmakla birlikte farklı ideolojik yönelimlere sahip iki gazetenin bu ideali nasıl kurguladığını çözümlemeyi amaçlamaktadır. Vatandaşlık devletin bireyle olan ilişkisini tanımlayan hukuki bir kavram olmasının yanında tarihsel süreç içerisinde bireyin diğer bireylerle ve toplumla olan ilişkisini de içeren sosyoekonomik ve kültürel bir anlamla da karşımıza çıkmaktadır. Bireyin hem devletle hem de toplumla olan ilişkisi bağlamında "makbul olanı" belirlemek ve bu doğrultuda topluma yeni vatandaşlar kazandırmak devletin ve toplumların devamlılığı açısından bir intiyaç olarak düşünülebilmektedir. Vatandaşıı etrafında şekillenen hak ve sorumluluk arasındaki çatışma ve uyuma dayalı ilişki devletin kendi değerlerini koruması ve devamlıığı açısından idealize ettiği vatandaş tipini de beraberinde getirmiştir. Bu bağlamda makbul olanı bulma ve onun üzerinde bir vatandaş inşa etme olarak da tanımlanabilecek "makbul vatandaş"।ığın ne olduğu ve nasıl kurgulandığı araştırmaya değer bir konudur. Bu doğrultuda Türk basınında önemli bir yere sahip Cumhuriyet ve Hürriyet gazetelerinin T. H. Marshall'ın sınıflandırdığı vatandaşlık haklarını nasıl yansıttığı ve haber üretim sürecinde neleri öncelediğini araştırmak çalışmanın amaçlarındandır. 1 Nisan 2007 ile 31 Aralık 2012 tarihleri arasındaki dönemde bahsi geçen gazetelerin ana sayfalarında çıkan vatandaşlık haklarına yönelik 721 haber Phillips ve Jorgensen, Fairclough'un eleştirel söylem çözümlemesi ile incelenmiştir. Sonuç olarak Cumhuriyet gazetesinin vatandaşlık haklarına yönelik haberlere kayda değer bir ölçüde yer verdiği ve laikliği ve cumhuriyeti koruyan vatandaş vurgusu ile haber ürettiği gözlemlenmiştir. Hürriyet gazetesinin ise eşitliği geri plana atan daha çok özgürlükler üzerinden vatandaş haklarını sunduğu ve aktif olmayan vatandaş söylemini vurguladığı sonucuna ulaşıımıştır.
\end{abstract}

Anahtar kelimeler: Makbul Vatandaş, Söylem, Türk Basını, Yurttaşlık Hakları

Atıf: Anamur, D. D. (2019). "Türk Basınında Makbul Vatandașlık Kurgusu: Hürriyet ve Cumhuriyet Gazetelerinin Haber Söylemleri Üzerine Bir İnceleme". Akdeniz Üniversitesi Iletișim Fakültesi Dergisi, (AKIL) Aralık (32), s. 141-165

1 Bu makale, 2013 yılında Ege Üniversitesi Sosyal Bilimler Enstitüsü Genel Gazetecilik Anabilim Dalında kabul edilen "Türkiye'de popülist muhafazakâr söylemin makbul vatandaş kurgusu: Muhafazakâr düşüncenin vatandaşıı söylemi üzerine bir inceleme" adlı doktora tezinden üretilmiştir. 


\title{
The Fiction of IdealCitizenship in TurkishPress: A Review on News Discourse of Hürriyet and Cumhuriyet Newspapers ${ }^{3}$
}

\begin{abstract}
Along with trying to understand how "ideal citizenship" is coded through time, this article also aims to analyze how two newspapers with different ideological tendencies fictionalize this ideal. In addition to being a legal concept which defines the relationship between state and individual, citizenship confronts us with a socioeconomic and cultural meaning which also includes the relationship of an individual with other individuals and society in historical process. Within the relational context of an individual with both state and society, determining "acceptable one" and providing new citizens to society accordingly could be considered as a need in terms of state and societies' continuity. The relationship based on conflict and harmony between right and liability shaped around citizenship has also brought the citizen type which is idealized by state in order to protect its own values and continuity in its wake. Defined as finding the ideal one and building a citizen over it within this context, analyzing what "ideal citizenship" and how it is fictionalized is a valuable topic to be studied. In this direction, how the newspapers of Cumhuriyet and Hürriyet, which have a significant place in Turkish press, reflect citizenship rights classified by Marshall and which topics they give priority in the process of making news are one of the objectives of this study. Being for citizenship rights, 721 news which were issued on home pages of relevant newspapers between April 1st 2007 and December 31st 2012 were analyzed with Philips, Jorgensen and Fairclough's critical discourse analysis.
\end{abstract}

Consequently, it was found out that Cumhuriyet emphasizes citizenship rights but in the meantime it specifies ideological enemies whereas Hürriyet, with a liberal attitude, represents rights more often in terms of freedoms and in response to this it ignores equality.

Keywords: Ideal Citizenship, Discourse, Turkish Press, Citizenship Rights

\section{Giriș}

Bu makalenin temel amacı T. H. Marshall'ın"Yurttaşlık ve Toplumsal Sınıflar" adlı eserinde sivil, siyasi ve sosyal haklar olarak sınıflandırdığı vatandaş haklarının; Türk basınında nasıl yer aldığını, haklara yönelik haber üretirken okuyucu olan vatandaşa ne yansıttığını ve haber metinleri üzerinden makbul vatandaşı nasıl kurguladığını çözümlemektir. Vatandaşlığın gelişim süreci ile ilgili kapsamlı çalışmalardan biri -1949 yılında sunduğu ve daha sonra genişleterek yayınladığı "Yurttaşlık ve Toplumsal Sınıflar" adlı makalesiyle - T. H. Marshall'a aittir. Toplumun gelişim çizgisi açısından önce sivil, sonra siyasal ve en nihayetinde sosyal haklara kavuşan vatandaştan bahseden Marshall, kapitalist sistem ile vatandaşlık arasındaki bağlantıyı kurarken toplumsal sınıflar, eşitsizlik, ücretlendirme ve eğitim gibi konular üzerinde durmuştur. Marshall coğrafi bir

3 This article was derived from the phd dissertation "The fiction of ideal citizenship of the populist conservative discourse in Turkey: An analysis of citizenship discourse of conservative opinion" which was acknowledged in Ege University The Institute of Social Sciences Department of General Journalism in 2013. 
anlam taşıyan "oluşma" ve daha çok işlevsel bir anlam taşıyan "ayrışma" gibi iki ayrı süreçle vatandaşlık kavramını ortaya koymaya çalışmıştır. Marshall'a göre vatandaşıı tarihsel açıdan üç ayrı eksenin bir araya gelmesiyle oluşmuştur. Marshall'ın bahsettiği üç eksen birbirinden bağımsız olarak farklı yüzyıllarda gelişmiş, bununla birlikte bu süreçler birbirleri ile örtüşmüştür. Ona göre 18. yüzyıl medeni(sivil) hakların ortaya çıktığı bir dönemdir. Bireysel özgürlük, konuşma özgürlüğü, düşünce ve adalet hakkı, hukuk önünde eşitlik gibi hakların resmi mahkemelerce savunulabildiği bir zaman dilimi vatandaşlığın ilk eksenidir. İkinci eksen siyasal boyuttur ve 19. yüzyılda ortaya çıkmıştır. Siyasal karar almada seçme ve seçilme hakkının geliştiği dönemdir. Üçüncü eksen ise 20. yüzyılda gelişen sosyal haklardır. Sosyal güvenlik ve ekonomik refah gibi geniş bir yelpaze içinde eğitim ve sosyal hizmet hakkını içermektedir(2006: s.6-9).

Marshall'ın bu ayrımını temel alan Turner'a göre bu üç eksen, üç kurumu karşımıza çıkarır: Mahkemeler, parlamento ve refah sistemi. Turner'a göre Marshall kapitalizmi vatandaşlık ve sosyal yaşamın karakterini belirlediği dinamik bir sistem olarak kavramsallaştırır. Burada bahsettiği şey; ekonomik kar ihtiyacı, modern devletin vergilendirme gerekleri ve refah hizmeti hakları arasındaki gerilimin yarattığı sosyal sistem$\operatorname{dir}(2008$ : s.110-111).

Makbul vatandaş kavramını Türkiye'de tartışmaya açan kişilerden biri olan Üstel'e göre vatandaşlık, öncelikle ahlaki bir yargıya işaret etmektedir. İyi ya da gerçek vatandaş olarak tanımlanmak kişinin davranışlarındaki ahlakiliğin olumlanmasıdır. İyilik ya da gerçeklik ise sadakat, vefakârlık ve militanlıkla anlamlandırılmaktadır. Burada Üstel bir gerilime dikkat çekmektedir. Vatandaşlık bir yandan seçme ve seçilmeye layık kişilere tanınan özel haklar ve görevler ile politik alanın ana eksenini oluştururken diğer yandan makbul/iyi vatandaş olmanın getirdiği sadakat, özveri gibi sıfatları taşıması niteliğiyle depolitize edilmektedir(1999: s.53). Bu açıdan makbul vatandaşı egemen güç tarafından çizilmişsınırlar çerçevesinde hareket eden bireyler olarak tanımlamak mümkündür. Üstel, makbul vatandaş yetiştirmenin en önemli yollarından birinin eğitim olduğunu vurgulamaktadır. Diderot'tan örnek veren Üstel, okulun görevinin o dönemde hükümdara gayretli ve sadık tebaalar, asillere faydalı vatandaşlar, toplum için bilgili, namuslu ve mümkün olduğu kadar sevimli unsurlar, ailelere iyi koca ve babalar, devlete düşünen büyük zekâlar, dine vicdanlı ve barışsever hizmetkârlar sağlamak olduğunu ifade etmektedir. Üstel, birçok örnekle güçlendirdiği eğitim yoluyla makbul vatandaşlar yetiştirmek fikrini, 19. yüzyılın sonunda en kararlı biçimde Fransa'nın gerçekleştirdiğini söylerken, bu eğitimin zorunlu hale gelmesini ve temel amacın vatandaşlara ölçülülük ve kendini hâkimiyet olduğunu belirtmiştir. Ulusun ahengi ve birliği güçlenmeli, ayrıca vatandaşlık bilinç ve duygusu, bireylerin davranışların kontrol altına alınarak, bireyler kendilerini diğer vatandaşlara bağlayan bağlara özen göstermelidir (2008: s.22-23). Eğitim devletlerin makbul vatandaş yetiştirme konusunda önemli araçlarından biridir. Ancak bu makale eğitimin yanında toplumu etkileme açısından önemli bir araç olan medyanın da makbul vatandaşlık konusunda etkili olduğu ön kabulüyle hareket etmektedir.

Bu makalenin soruları şunlardır: sivil, siyasi ve sosyal haklar haberlerde nasıl ele alınmaktadır? Kadınlar ve kadın hakları haberlerde nasıl temsil edilmektedir? Toplumsal hareketler ve aktif vatandaşlık haberlerde nasıl yer bulmaktadır? Bu sorular 
ışığında makalenin temel hipotezleri ise şunlardır: Gazeteler sivil, siyasi ve sosyal haklara haberlerde yer verse de bu tür haberler siyasal aktörlerle ilişkilerinden bağımsız değildir. Gazeteler kendi yapısal duruşlarına uygun idealler belirlemekte ve haberlerin ortaya çıkışında bu idealler üzerinden hareket etmektedir. Kadınlar ve toplumsal cinsiyete dayalı sorunlar olgusal olarak haberleşememektedir. Toplumsal hareketler ve aktif vatandaşıı medyada yeterince kendine yer bulamamaktadır.

Bu soru ve hipotezler çerçevesinde 1 Nisan 2007 ile 31 Aralık 2012 tarihleri arasında ulusal sol kanatta konumlanan Cumhuriyet ve ana akım çizgide olan Hürriyet gazetelerinin ana sayfalarında çıkan haberler eleştirel söylem analizi yöntemi ile ele alınmıştır.

\section{Vatandașlık Üzerine Tanımlar}

Vatandaşlığın literatürde yer alan tanımları onun devletle olan hukuki bağına vurgu yapsa da 21. yüzyılda bu tanım yeterli görünmemektedir. En basit açıdan ele alındığında; birey açısından güvenlik ve bir yere/gruba ait olma duygusu ile ortaya çıkan vatandaşıık, devlet açısından kendini devam ettirme ve gelecek kuşaklara taşıma olarak karşımıza çıkmaktadır. Vatandaşıı genellikle devletle birey arasındaki hukuki bağ üzerinden tanımlanmakla birlikte ona yöneltilen atıflar onun hukuki ve niceliksel boyutunu aşmakta niteliksel ve sosyal yönüne vurgu yapmaktadır. Walzer, vatandaşlığı politik bir topluluğa üyelik olarak tanımlarken, vatandaşlığın her türlü ayrıcalığa sahip olduğunu ve üyeliğin her türlü sorumlulukla donatıldığını söylemiştir(1995: s.211). Leca vatandaşlık için; aile, soy ya da senyörlük cemaatlerinden farklı, kurumsal bütünlük iddiasıyla ortaya çıkmış ekolojik alanı tanımlayan bir sivil toplum (yasaya bağlı siyasal toplum) ifadesini kullanarak vatandaşı ı̆ın sivil boyutuna değinmektedir (1998:s.20). Ünsal ise vatandaşı uyruktan farklı olarak aktif bir biçimde siyasal yaşamda etkinliği olan sadece haklarının değil sorumluluklarının da bilincinde olan kişi(1998: s.4) olarak tanımlamaktadır.Mouffe ise vatandaşlığın aktif rolünü vurgulayarak pasifize edilmiş vatandaşlık fikrine karşı çıkmaktadır: "Yurttaş, politik bir topluluğun üyesi olan, kolektif bir girişime katılan, izole bir birey gibi değil ortak bir perspektiften itibaren hareket eden biridir" (1999: s.137) demektedir. Berktay da benzer şekilde "yurttaş, salt sistemin verdiği görevleri sorgusuz yerine getiren, uyumlu ve itaatkâr bir insan değil, kendisi için düşünebilen, yargılayan ve eyleyen bunun sonuçlarını göze alabilen özerk bireydir” (2010: s.50) diyerek aktif bir vatandaşlık profilini dile getirmektedir. Üstel'e göre Antik Yunan'dan günümüze kadar gelen süreç içerisinde erdem olma niteliğini koruyan vatandaşlık burjuva devriminden sonra kapitalizmin beraberinde getirdiği hak ve görevler sistemi ile şekillenerek olgusal bir niteliğe bürünmüştür (1999: s.51). Barber'e göre modern devletlerde vatandaşlığın temeli ve ilk dayanağı topraktır. Bununla birlikte Batı toplumlarına bakıldığında bu ilk dayanağa ek olarak kan, kişisel sadakat, mülki idare, ortak inanç, ekonomik sözleşme, siyasal sözleşme, ortak süreçlere ve ortak hedeflere bağlıık sıralanabilir (1995: s.271). Jean Leca ise modern vatandaşlığa farklı bir gözle bakarak üç özellik çerçevesinden konuyu ele almaktadır. Bunlardan ilki; hak ve yükümlülükleri birlikte getiren bir siyasi kolektivitedeki yasal statüdür. İkinci olarak, siyasi işbölümündeki statüsüdür. Birey, özel, mesleki ve iktisadi rollerden farklı belirli bir takım toplumsal rol üstlen(ebil)mektedir. Üçüncü olarak vatandaşlık "iyi” vatandaşın karakterinde olması gerektiği düşünülen bir ahlaki nitelikler bütünüdür (1993: s.57). 
Modern vatandaşın bu üç özelliği onu siyasi bir birliğe yasal bir statü ile bağlarken bireyin ahlaki değerlere sahip olması onu iyi birer vatandaş yapmaktadır.

21. yüzyıl vatandaşlık açısından yeni kavramların ya da Antik Yunanın unutulan kavramlarının ortaya atıldığı dönem olmuştur. Çok kültürlülük, kökeni Stoacılara kadar dayanan dünya vatandaşlığı veya birçok devletin belirli koşullar altında bir araya gelip ortak değerlere sahip olmasının yarattığı birlik vatandaşı̆̆ı (Avrupa Birliği Vatandaşı̆ğı gibi), sivil toplumun önemini vurgulayan sivil, cinsiyetçi/cinsyansız vatandaşlık, evrensel vatandaşlık gibi yeni formlar üzerine düşünülmeye başlanmıştır.

\section{Ahlaklı Vatandaștan Makbul Vatandașa}

Bireyin devlet ve toplumla olan ilişkisi tarihin geçmiş sayfalarında topluma yararlı vatandaş çerçevesinde gelişmiştir. Bookchin "politik anlamda berrak bir vatandaş imgesi, ilk olarak Antik Yunanlılarda görülür" (1999: s.92) demekte, Heater ise bu başlangıcı başka bir katılımcı siyasal toplum modelinin daha önce olmadığı düşüncesiyle Spartalılara dayandırmıştır (2007: s.16). Bu sebeple vatandaş kimdir ve nasıl olmalıdır sorularına cevaplar ilk olarak bu topraklardan çıkmıştır.

Antik Yunan'da birçok düşünür ideal vatandaşı eğitim yoluyla yetiştirme eğilimindedir. Berktay'ın da belirttiği gibi 'Klasik Çağ'da 'özgür insana yaraşan' öğrenim, düşünceyi ve aklı özgürleştiren öğrenimdir, çünkü ancak bu nitelikleriyle kişi içinde bulunduğu kamusal ortama katkıda bulunabilir" (2010: s.111). Bu anlamda kendini kamusal alanda temsil edebilme yetisine sahip, yalnızca sorumluluklarının değil haklarının da bilincinde vatandaş profiline sahip olmak iyi bir eğitim ve kültürel birikimi de beraberinde getirmektedir.

Tarihsel süreç içerisinde hem küreselleşmenin etkisi hem ulus devlet anlayışının farklııık göstermesi hem de sosyoekonomik dönüşümler vatandaşlık fikrini başkalaştırmıştır. Ulus devletin en vazgeçilmez unsurlarından biri olarak görülen vatandaş uzun bir süre sadece statüsel ve hukuksal anlamda devletlerin gündemini meşgul etmiştir. Vatandaşlığın, 1980 ’ler öncesinde çok da fazla politik gündemi meşgul etmediğini ve yalnızca ırk ve göç sorunları ile bağlantılı olarak tartışıldığını söyleyen Hall ve Held'e göre 1980 'ler vatandaşlığın politik gündeme geri dönüşünü de beraberinde getirmiştir (1995: s. 169-170).

Aristoteles'ten Rousseau'ya oradan da cumhuriyetçi düşünceye kadar vatandaşlıkla ilgili temel kavramlardan biri olan ortak iyiye hizmet ve vatandaşlık erdemi düşüncesi Tunçel'e göre çağdaş demokrasilerde biraz farklılaşmaktadır. Ona göre çağdaş demokrasilerdeki vatandaşlar farklı çıkarlara bağlanışları sebebiyle ortak iyiden ayrımaktadırlar. Bununla birlikte vatandaş erdeminin sıklıkla vurgulanması hoşgörüsüzlük ve fanatikliğin de önünü açabilmektedir. Bu sebeple modern dünya çağdaş intiyaçlara cevap verebilecek yeni bir sadakat nedenine ihtiyaç duymaktadır. Bu bağlamda liberal ve toplulukçu düşünce birbirinden ayrılmakta toplulukçu gelenek vatandaşları arasında ortak iyiyi öncelerken, liberal düşünce birey ve bireyin iyilerine ilişkin temeli dikkate almaktadır (2010: s.300).

Temel olarak ideal/makbul vatandaşlık fikri toplumsal birlik fikri ile ortaya çıkmış bir 
kavram olarak nitelendirilebilir. İnsanların bir arada yaşama isteği ile birlikte gelişen toplumsal yaşam, özel mülkiyet kavramının ortaya çıkması ile karmaşık bir hal almıştır. Antik Yunan'ın felsefi düşüncelerinde ön plana çıkan özgür ve erdemli vatandaşlar yaratma düşüncesi kurulan siyasal birliğin en ideal şeklini temsil etmektedir. Ortaçağ felsefesi ise bireylerin makbul hallerini sonsuz itaat ve kiliseye bağlılık olarak belirlemiştir. Aydınlanma ve beraberinde gelişen toplumsal hareketler insanı tekrar toplumda önemli bir noktaya getirerek, özgürlük, eşitlik ve kardeşliği toplumsal düzenin yeni ilkeleri olarak belirlemiştir. Özgürlüğün getirdiği girişimcilik, kapitalist dünyanın kapılarını açarken, eşitlik ilkesi fırsat eşitliği ilkesine doğru evrilmiştir.

\section{Türkiye’de Vatandașlığın Tarihsel Serüveni}

Türkiye'de hukuki anlamda hakların gelişimi Avrupa'dan daha sonraya 19. yüzyıla denk gelmektedir. 1808 Sened-i İttifak, 1839 Gülhane Hatt-ı Hümayunu ile şekillenen Tanzimat Dönemi ve bu dönem içerisinde ele alınabilecek 1856 Islahat Fermanı ile Birinci ve İkinci Meşrutiyet Dönemleri ile Osmanlı Devleti'nin birçokları tarafından ilk anayasası olarak kabul edilen 1876 Kanun-i Esasi'si; Osmanlı Devleti'nin devlet ile birey arasındaki ilişkisini düzenleyen metinler ve dönemler olarak ele alınabilir.

Berkes'e göre Osmanlı Devleti siyasi bir güç olduktan sonra Hıristiyan devletlerle karşı İslamiyet'i tutmuştur (2002: s.29). Kendi topraklarındaki Hıristiyanları Müslüman yapma politikasına gitmemesi ve onlara farklı vergiler uygulaması Osmanlı Devleti'ndeki ilk millet ya da vatandaşlık anlayışının dinsel bir temel üzerinde kurulduğunun göstergesi olarak kabul edilebilir. Müslüman olmayanlar ikinci sınıf tebaa sayılmasına karşın Sünni mezheplerden birine mensup Müslümanlar Osmanlı Devleti'ne rahatça yerleşebilme hakkına sahiptir (Aybay, 1982: s.24-25).Osmanlı Devleti'nin ilk yazılı vatandaşlık çalışmaları bu yüzden Müslim ve gayrimüslim ayrımını ortadan kaldırmak amacı ile gerçekleştirilmiştir. 1869 Tabiiyeti Osmaniye Kanunnamesi dinsel kurallardan bağımsız ilk vatandaşlık kanunudur (Fişek, 1959: s.6-7).

Kuruluş dönemi Türkiye'sinde vatandaşlık ile ilgili gelişmeler yasal ve sosyokültürel/ kurumsal olmak üzere iki ana koldan ilerlemiştir. İlk olarak, Türk vatandaşlığı 1924 Anayasasının 88. maddesinde "Türkiye ahalisine din ve ırk farkı olmaksızın vatandaşıı itibariyle Türk ıtlak olunur" şeklinde tanımlanmıştır. Geliştirilmiş ve genişletilmiş bir vatandaşlık anlayışı, nüfus azlığının psikolojik bir etkisi ile olabildiğince çok kişinin Türk vatandaşı olması amacını güttüğünü söylemek mümkündür (Aybay, 1998: s.27). İkinci olarak Türk Tarih Kurumu ve Türk Dil Kurumu yeni kurulacak ulusun kültürel değerlerini araştırma ve ortaya çıkarma, tarihsel mitlerini bulma ve ulusal kimliğin oluşumuna etki edecek her türlü değeri ortaya çıkarmak amacıyla kurulmuştur. Schnapper'e göre Atatürk vatandaşlık ülküsünün üstünlüğünü olumlamış ve vatandaşlar arasında eşitliği öngörmüştür. Ondaki modern ulus fikrinin gerektirdiği anlayışla tikel aidiyet ve farklılıkları vatandaşı ık kavramı ile aşma yoluna gitmiştir. Bu sebeple kamu alanında laiklik, bu eşitliğin ve tarafsızlığın yaşatılması için önemlidir(1995: s.10-11).Bu noktalardan hareketle erken cumhuriyet döneminin ideal vatandaşları hukuksal anlamda kendini bilen ve ulus bilincini benimsemiş, ortak dil ve kültür çerçevesinde bir araya gelmiş vatandaşlardır demek mümkündür. 
Kadıoğlu'na göre Türkiye'de siyaset vatandaşa nasıl mutlu olunacağını onların iyiliği adına gerçekleştirme çabasına gitmiştir. Ortada bir medeniyet projesi vardır ve bunu hayata geçirmekle görevli kişiler de izci rolündeki vatandaşlardır (1999: s.11). Üstel, erken cumhuriyetin oluşturmak istediği makbul vatandaş kurgusunda birkaç noktaya dikkat çekmektedir. Bunlardan ilki cumhuriyet rejiminin, eğitim yoluyla ulus devletin cumhuriyetçi vatandaşların yetiştirilmesi amacı güttüğüdür (2008: s.128). İkincisi, vatandaşlar topluluğu oluşturma ideali çerçevesinde topluluğa ait coğrafi sınırları belli bir mekan (vatan/yurt) belirlemek ve daha sonra bu mekana (vatana/yurda) sadakat ve vatanseverlik duygusunun kazandırılmaya çalışılmasıdır. (Üstel, 2008: s.156-157). Üçüncü nokta ise vatandaşların niteliği ile ilgilidir. Cumhuriyet'in yaratmak istediği vatandaş medenilik ve vatanseverlik eksenleri üzerinde yükselen medeni ve vatansever vatandaştır ve bu vatandaş cumhuriyetçi ve laik bir ahlak anlayışına sahip olmalıdır (Üstel, 2008: s.175). Üstel'in de dikkat çektiği gibi Cumhuriyetçi ideoloji ideal bir devlet düzeni kurgusu içerisinde hareket etmektedir. Bunun için gerekli unsurlardan ilki bu ideali yaşatacak vatandaşlar yetiştirmek, ikincisi ise bu idealin yaşanacağı mekânı belirlemek olmuştur.

Türkiye'nin siyaset arenasındaki en önemli dönüm noktalarından biri çok partili hayata geçiş ve Demokrat Parti iktidarıdır. Amerika tarzı liberal ideolojinin özellikle Marshall Planı ile şekillenmeye başlandığı süreçte vatandaşlık algısı da farklılaşmaya başlamıştır. Bu dönemde Demokrat Parti'nin liberal politikaya uygun hareket ettiği ve devletçilikten uzaklaştığı gözlemlenmektedir. Cumhuriyetin 75 Yılı adlı eserde yer alan Demokrat Parti'nin 1957 seçimlerinde kullandığı afişte "Mesut, zengin, kuvvetli, hür ve şerefli bir vatan istiyorsan reyini Demokrat Partiye ver" (1999:s.419) ibaresi yer almaktadır. Demokrat Parti'nin seçmenlerinden beklentisi zengin, güçlü, bağımsız ve şerefli bir vatan istemeleridir. Bu ifade, vatandaşın vatansever bir niteliğe sahip olması üzerinde şekillenmekle birlikte "zenginlik" kavramı da vatandaşlık literatüründe kuvvetlenmeye başlamıştır. Ahmad "Cumhuriyetin savaş öncesi dönemindeki sistemin en belirleyici özelliği bireyin toplum için çalıştığı anlayışıdır. Demokratlar bu anlayıştan vazgeçmediler gerçi, ama bireyin refahını daha çok vurguladılar" (1999: s.287) diyerek bir anlamda cumhuriyetçi vatandaştan refah isteyen vatandaşa geçildiğini vurgulamıştır.

1960 Darbesi devletle birey arasındaki ilişkiyi yeniden şekillendiren bir anayasa metninin ortaya çıkmasıyla sonuçlanmıştır. Bu dönemde sivil, siyasi ama en çok da sosyal haklar açısından farklılaşmalar yaşanmaya aktif vatandaş düşüncesi özellikle canlanmaya başlanmıştır. Ancak bu süreç uzun sürmemiştir. Tanilli'ye göre Türkiye'de vatandaşlık açısından sosyal hakların gelişimi de bu dönem içerisinde başlangıç aşamasında kalmıştır. Tekelci burjuvazi güç kazanırken orta sınıf buna karşı durmak için çaba sarf etme çabasına gitmiştir (1982: s.94-99). Bu süreç başka bir askeri darbeyi de beraberinde getirmiştir. 1980 Darbesi sonrası dönemde okutulan vatandaşlık kitaplarındaki millet tanımlamasında din ve ırk vurgusu yapıldığını söyleyen Caymaz'a göre "Türkiye'de yaşayan tüm fertler milletin parçasıdır fakat dini düzlemde bazıları diğerlerinden daha fazla milleti meydana getiren gruba dahildir. Söz konusu olan, söylem düzeyinde içerici ama pratikte dışlayıcı bir millet anlayışıdır. Bu dışlama sadece Yahudi, Ermeni, Rum gibi dini azınlıkları değil, dini İslam olsa da devletin kolladığı, 
örgütlediği ve kontrol ettiği resmi İslam'ın dışında kalanları da kapsamaktadır"(2007: s.49). Gürses'e göre 1980'lerle birlikte militan vatandaşlık algısı yeniden canlanmaya başlanmıştır. 12 Eylül darbesi geleneksel ve dinsel kimliklerin yükselişinin yaşanmasına sebep olmuştur (2011, s.298). Özelleştirmelerin etkin bir şekilde devam ettiği 80'li yıllarda devlet, baba rolünden çıkmış, gözetleyici bir rol üstlenmiştir. Devletin vatandaşa yüklediği anlam sadakat, fedakârlık ve vatan sevgisi ile yoğrulurken, vatandaş da haklarından çok görevlerine yönelen bir tutuma yönelmiştir.

Özetle, Türkiye'de vatandaşlık algısının genel anlamda devletin belirlediği sınırlar etrafında şekillendiğini söylemek mümkündür. Bu konuda yapılan çalışmalar iki farklı noktaya dikkat çekmektedir. Erken cumhuriyet döneminde vatandaşın devlete karşı sorumlulukları ön plandadır. Devlet, vatandaşlarından sorumluluklarını yerine getirecek cumhuriyetçi bireyler olmalarını beklemiştir. 1950'lerden sonra ise seçkinci liberal düşünce ekseninde vatandaşlık kurgusunun sınırlarının kapitalizmin bireyle olan ilişkisi üzerinden inşa edilmiştir.

\section{Araștırmanın Yöntemi ve Kapsamı}

Çalışmanın temel araştırması medya metinlerindeki vatandaşlıkla ilgili söylemin analizidir. Söylemi ele almak ve ona her anlamılla bakabilmek onu eleştirmekten geçmektedir. Eleştirel söylem analizi de bu doğrultuda belirli bir söylem kurgusu içerisinde egemen güç/iktidar ile ortaya çıkan adaletsiz/eşitliksiz durumu ortaya çıkarma amacındadır. Söylem, hem nicelik hem de nitelik açısından ele alınan bir yapıya sahiptir. Phillips ve Jorgensen, Fairclough'un eleştirel söylem analizi çalışmalarından da etkilenerek söylem analizinin 6 aşaması olduğunu vurgulamıştır. Bunlardan ilki araştırma probleminin seçimidir; eleştirel söylem analizi genellikle o toplumdaki adaletsizlik ve eşitsizliği ortaya koyma eğilimindedir. Bu sebeple araştırmanın konusu ve sorunsalı bu amaçta olmalıdır. İkincisi araştırma sorularının formüle edilmesidir. Bunu yaparken konu olan söylemin ait olduğu toplumdan ayrı düşünülmemesi gerekmektedir. Üçüncü aşama materyallerin seçimidir. Söylem analizine konu olan gazete, dergi, reklam vb. materyallerin nasıl seçileceği ve onlara nasıl ulaşıldığı ile ilgilidir. Dördüncüsü transkripsiyondur. Araştırmanın amaçları belirlenmeli ve transkripsiyon buna göre yapılmalıdır. Beşinci aşama analizdir. Araştırmanın en önemli ve ayrıntılı aşamasıdır. Burada metnin nasıl üretildiği ve nasıl tüketildiği (algılandığı) analiz edilmektedir. Son aşama ise sonuçlardır. Burada araştırma başındaki amaçlar ön plana çıkmaktadır. Sonuçlar kısmında söylemdeki eşitliksiz ve adaletsiz durum ortaya konulmalıdır (2002:s. 7789). Bu noktalardan hareketle araştırmanın temel problemi Türk basınında makbul vatandaş kurgusunu nasıl inşa edildiğidir. Bu doğrultuda makalenin kuramsal kısımda değinilen noktaları yol gösterici olacaktır.

Sivil, siyasi ve sosyal haklar haberlerde nasıl ele alınmaktadır? Toplumsal hareketler ve aktif vatandaşlık haberlerde hangi ölçüde ve nasıl yer bulmaktadır? Soruları araştırmanın temel sorularını oluşturmaktadır. Bu soruların karşılığında makalenin temel hipotezleri ise şunlardır: Gazeteler sivil, siyasi ve sosyal haklara haberlerde yer verse de bu tür haberler siyasal aktörlerle ilişkilerinden bağımsız değildir. Gazeteler kendi yapısal duruşlarına uygun idealler belirlemekte ve haberlerin ortaya çıkışında bu idealler üzerinden hareket etmektedir. Toplumsal hareketler ve aktif vatandaşlık 
medyada yeterince kendine yer bulamamaktadır.

Üçüncü aşama materyal seçimidir. Araştırmanın evreni için seçmiş olduğumuz gazeteler hem Türkiye'nin en çok satan gazeteleri arasında yer almakta hem de farklı ideolojik konumlara sahiptir. Bu doğrultuda seçilen gazeteler; anaakım/milliyetçi çizgideki Hürriyet Gazetesi ile ulusal sol çizgide olan Cumhuriyet gazetesidir. Gazetelerdeki haberler, seçilen 4 soru üzerine şekillenen temalar doğrultusunda ele alınmakta ve analiz edilmektedir. Araştırmada 1 Nisan 2007 ile 31 Aralık 2012 tarihleri arasındaki ana sayfa çıkan haberler incelenmiştir. Bu dönemde gazetelerin ana sayfasında çıkan haberler araştırma soruları çerçevesinde ele alınmıştır. Gazetelerin ana sayfalarında çıkan haberlerin tercih edilmesinin sebebi, bu sayfalarda yer alan haberlerin hem vatandaşların gündemi üzerinde daha etkili olması hem de gazetelerin en çok önem verdikleri haberlere bu sayfalarda yer vermeleridir. Bu sebeple araştırmada seçilen metinler birinci sayfaya çıkmış haberlerden seçilmiştir. Belirtilen tarihler arasında vatandaşlık ve bireyin toplumsal konumuna doğrudan etki eden gündem konuları araştırmanın örneklemini oluşturmaktadır. Dördüncü aşamada ise ele alınan haber metinleri amaçlar doğrultusunda konularına göre ayrıştırılarak analiz aşamasına geçilmiştir. Beşinci aşamada her haber teması kendi yapısal özelliğine göre tekrar sınıflandırılıp analiz edilmiştir. Altıncı aşamada ise elde edilen bulgulardan çıkan sonuçlar yorumlanmıştır.

\section{Araștırmanın Bulguları ve Analiz}

Gazetelerin ana sayfaları incelendiğinde vatandaş hakları ile ilgili her iki gazetenin de farklı söylemler geliştirdiği gözlemlenmiştir. Bu bağlamda sivil haklar, siyasal haklar, sosyal haklar ve kadın hakları olmak üzere üç ana konu belirlenmiş ve haberler bu üç konu çerçevesinde şekillenen temalar üzerinden analiz edilmiştir. İki gazetede vatandaş hakları ile bağıntılı toplam 721 haber tespit edilmiştir. Cumhuriyet gazetesinde 506, Hürriyet gazetesinde ise 215 haber vatandaşlık hakları üzerinedir.

\subsubsection{Cumhuriyet Gazetesine Yönelik Söylem Analizi}

Cumhuriyet gazetesinin ana sayfasında çıkan haberler vatandaşlık hakları ekseninde incelendiğinde karşımıza çıkan temalar şu şekildedir.

Tablo 1. Vatandaşlık Hakları Eksenine Dair İncelenen Haber Sayısı- Cumhuriyet Gazetesi

\begin{tabular}{|l|c|}
\hline \multicolumn{2}{|c|}{ VATANDAŞLIK HAKLARI EKSENI } \\
\hline TEMALAR & iNCELENEN HABER SAYISI \\
\hline Sivil Toplum ve Sivil Toplum Örgütlerinin Temsili & 57 \\
\hline Sendikaların Temsili ve Grevler & 123 \\
\hline İnsan Hakları ve Özgülükler & 31 \\
\hline Demokratik Haklar ve Meclisin Üstünlüğü & 19 \\
\hline Yüksek Yargının ve Mahkemelerin Temsili & 28 \\
\hline Sosyal Haklar: Yoksulluk, İşsizlik ve İşçi Ölümleri & 151 \\
\hline Kadın Hakları & 97 \\
\hline TOPLAM & $\mathbf{5 0 6}$ \\
\hline
\end{tabular}


Cumhuriyet gazetesinde haklarla ilgili olarak öne çıkan ilk tema Sivil Toplum ve STK'ların olumlu temsilidir. Genellikle laik demokratik ve cumhuriyetçi bir düzen için yapılan eylemler ile hükümet eleştirisinin yapıldığı faaliyetler bu temada dikkat çekmektedir. Devrimci İşçi Sendikaları Konfederasyonu (DiSK), Kamu Emekçileri Sendikaları Konfederasyonu (KESK), Atatürkçü Düşünce Derneği (ADD), Türkiye Gençlik Birliği, Türkiye Gazeteciler Cemiyeti, Eğitim Sen, Türkiye Gazeteciler Sendikası gibi sol ve ulusal sol eğilimli sivil toplum örgütlerinin ve sendikaların haberlerine yer veren gazete, öğrenci eylemlerini de sıklıkla duyurmuştur. TÜSIAD gibi sermaye gruplarının söylemlerine ise laikliğin ve sosyal adaletin sağlanması yönündeki ifadeler ön plana çıkarılarak yer verilmiştir. Gazete özellikle hükümet karşıtı birçok sivil toplum hareketi eylemlerine sıklıkla ana sayfasında yer vermiştir. "On binler Erdoğan'a 'Dur' dedr” (09. Nis.07), "Yüz Binlerden AKP'ye Uyarı" (13.Nis.08), "35 Örgütten Miting: 'Darbeciler Yargılansın" (20.Eyl.10), "Türbansız Anayasa" (14.Ara.07), "Sivil Toplum: 'Katıımcı Anayasa" (10.Nis.10), "Öğrenciler Ayakta" (28.Ara.12), "On Binlerden Erdoğan’a Yanıt: Evet, Solcular Karşı Çıkıyor?’ (07.Nis.08), "Diyarbakır Savaş Alanı" (15.Tem.12), "Ahmet ve Nedim'in Gazeteci Arkadaşları Yürüdü: 'Yansak da Dokunacağız" (19. Eyl.11), "Vardiya Bizde Platformu'ndan Silivri Cezaevi Önünde Nöbet Eylemi: 4 Nöbet Çadırı" (10.Eyl.11), "Dizi Emekçileri İsyan Ettı" (25.Ara.10), "Cumartesi Anneleri: 300 Haftadır Eylemdeler Ama Sonuç Yok" (26.Ara.10), "NATO Protestoları" (05. Nis.09), "Işveren Bildiriyle Uyardı" (11.Şub.09), "Öğrenciler Sokakta: Yıldönümünde YÖK Protestosu” (07.Kas.07), "İsrail'e Çağlayan'da Protesto” (06.Haz.10) gibi haberlerde tüm bu çeşitliliği görmek mümkündür. "Türbansız Anayasa" manşetli ve "Işveren Bildiriyle Uyardı" başlıklı haberde kullandığı "AKP hükümetini yerel seçim ve dış politik gelişmelere öncelik vererek krize karşı kapsamlı paket hazırlamamak ve bu süreci yönetememekle suçlad»", "TÜSIAD Başkanı Arzuhan Doğan Yalçındağ, yeni anayasanın Cumhuriyetin 84 yıllık kazanımlarını, rejimin laiklik gibi temel niteliklerini değiştirmemesi gerektiğini belirtti" gibi ifadelere yer vererek işveren kuruluşların sadece laiklik vurgusu ve hükümet aleyhindeki sözlerini ön plana çıkarmıştır. Gazetenin kendi söylemlerinin desteklendiği bu ifadeler aslında bu kurumların araçsallaştığının da bir göstergesi olarak kabul edilebilinir."Öğrenciler Ayakta” manşeti ile duyurduğu haberde ise “ODTÜ ‘Devrim' Stadında Binlerce Öğrenci Buluştu. Çok Sayıda Üniversitede Eylem Vardı" ifadesine yer vererek öğrenci hareketlerini haberleştirmiştir. ODTÜ'lü öğrencilerin "Devrim stadında AKP'yi ve Erdoğan'ın ODTÜ ile ilgili sözlerini protesto" edişine dikkat çeken gazete "ODTÜ'lü öğrenciler iki günlük işgal eylemlerini Devrim stadında gerçekleştirdikleri "ODTÜ Ayakta AKP'ye Direniyor” şenliği ile sonlandırdı" ifadesi ile de bu eylemi şenlik olarak nitelendirmiş ve olumlamıştır. "Yüz binlerden AKP'ye Uyarı" adlı haberde ise Türk bayraklı ve "Yaşasın Tam Bağımsız Türkiye" dövizli bir fotoğraf kullanarak "Ankara, dün Cumhuriyet mitinglerindeki coşkuyu bir kez daha yaşadı. AKP'nin yeniden iktidara geldiği 22 Temmuz genel seçiminden sonra, hükümete karşı en kitlesel eylem gerçekleştirild?' ifadesine yer vererek sivil toplumun Adalet ve Kalkınma Partisi'ne karşı olduğunu dile getirmiş yine mitinge katılanların "Kemalist devrimin devamı için milat niteliğinde", "ulusal egemenlik, ulusal devlet ve tam bağımsızlık", "Kadınları kafes arkasına çekmek isteyen zihniyete karşıyız. Onlar, Atatürk'ün kızları olduğumuzu anlayana kadar buradayız", "Emperyalizmin parçala, böl, yönet tezgâhına alet olmayalım” sözlerini ön plana çıkararak cumhuriyetin 
kuruluş yıllarındaki cumhuriyetçi militan vatandaşlığın tekrar canlanması gerekliliğine vurgu yapanları olumlamıştır. Dikkat çeken diğer bir nokta hak savunucuları olarak sivil toplumun ve STK'ların gösterilmesidir. Her ne kadar ideolojik kaygı taşısa da toplumda değişiklik yaratacak güç olarak halkı görmesi ve halk hareketlerine önem vermesi gazetenin haklar açısından olumlu tutumunu göstermektedir. Ancak yine kendi görüşünde olmayan grupları yok sayarak haberlerinde yer vermemesi ya da haberlerde yer bulsa da olumsuzlaması tek tip vatandaş tipinin arzulandığı imajını doğurmaktadır.

Bu konuda dikkat çeken diğer tema sendikaların temsili ve grevlerdir. Gazete çok sık olarak işçi grevlerine yer vermiştir. Gazetenin en çok dile getirdiği grev ve eylemlerin başında TEKEL işçilerinin grevi bulunmaktadır. İkinci dikkat çeken nokta ise grev ve eylemle başarı sağlanabileceğine yapılan vurgudur. Üçüncü dikkat çekici nokta ise "emek", emekçi”, "direniş", "onur", "dayanışma", "omuz omuza” gibi genellikle sol literatürde geçen ifadelerin sıklıkla kullanılmasıdır. Dördüncü dikkat çeken nokta ise 1 Mayıs İşçi ve Emekçi Bayramı'na yapılan vurgudur. Ayrıca işçi ve sendikalar üzerindeki baskı da bu haberlerde sıklıkla dile getirilmektedir. TEKEL işçilerinin yaptığı direnişi bu süreçte hemen her gün yayınlayan gazete "TEKEL İşçileri Yılmıyor" (24.Oca.10) adlı haberinde "Işçiler kar, soğuk demeden 41 gündür direniyor, direnişe destek büyüyor" diyerek eyleme olumlu bir dille yaklaşırken, "TEKEL Iş̧̧isinin Dostu Cumhuriyet" (28. Şub.11), başlıklı haberinde diğer gazetelere oranla Cumhuriyet gazetesinin TEKEL işçileri ile ilgili yaptığı haber sayısına dikkat çekerek bu işçilerin yanında olduğunu ve başarılarında payı olduğu vurgusunu yapmıştır. "Direnen İşçi kazandi" (29.Kas.07), "TEKEL İşçisinin 4/C Zaferi” (02.Mar.10), "Direnen BAT İşçisi Kazandı" (20.Nis.11), "Örgütlenmenin gücü”: (29.Ağu.07), "THY Işçilerine Umut" (19.Eki.12) adlı haberlerde "Danıştay, '30 günlük' geçiş süresine durdurma kararı verdr', "Sendika direndi ve kazandı", "Havada grev yasağı kalktı" gibi ifadeler kullanarak ve direnişlerin sonunda işçilerin başarı sağladığını vurgulayarak grevlerin gücünü dile getirmiştir. Yine benzer bir şekilde "DiSK Direniyor" (23.Ara.10), "Sosyal Güvenlik Tepkisi: Emekçiler Yürüyecek” (11.Oca.08), "Sokak Meclisi” (09.Eki.11), "En Büyük Uyarı”(26.Kas.09), "Greve Yoğun Katılım" (21.Nis.11) gibi haberlerde kullandığı "on binler torba yasaya karşı omuz omuza”, "on binlerce emekçi, 'insanca bir yaşam, eşit- özgür-demokratik bir Türkiye' için miting yaptı", "Emekçilerin, ezilenlerin hakkını arayan kamu çalışanlarının grevine yüz binlerce kişi katıld” gibi ifadelerle katıımın sayısının fazlalığına vurgu yaparak bu eylemlerin büyük bir güç olduğunu ifade etmiştir. "İşçilere Dayak" haberinde "İzmir'de, Bayraklı'nın ilçe yapılması ve Karşıyaka Belediyesi sınırlarından çıkarılmasıyla Kent AŞ şirketindeki işlerine son verilen bir grup işçinin, belediye şantiyesi önündeki eylemleri 100 gündür sürüyor" ifadesine yer vererek Cumhuriyet Halk Partili belediyeye karşı yapılan eylemin sanki hükümetin uygulaması ile bu işçileri işsiz bıraktığı imajı yaratılmaya çalışılmıştır. 100 günden beri eylem yapan Kent AŞ işçilerinin Cumhuriyet Halk Partili belediyece işten çıkarıldıklarına vurgu yapmayan gazete 100 gündür eylemde olan bu işçileri sadece bir kez haberleştirmiştir. Gazete ayrıca itfaiyecilerden, Türk Hava Yolu çalışanlarına, eğitimcilerden sağlık çalışanlarına kadar birçok sendika ve iş koluna dair grevler olumlu bir dille haberleştirilmiştir. Hemen her gün bir işçi eylemine ya da emeğe dair sivil toplum örgütünün eylemlerini içeren haberlerin çıktığı ana sayfada sıklıkla "AKP iktidarına karşı" ifadesinin kullanılması dik- 
kat çekmektedir.

Cumhuriyet gazetesinin bu konu altındaki diğer teması insan hakları ve özgülüklerine çektiği dikkattir. Gazetede sıklıkla polis şiddetine dair haberler çıkarken, insanların kendilerini özgürce ifade etme haklarının yoksunluğuna değinilmiştir. Gazete ayrıca Türk halkının da işkenceyi normalleştirdiği veya kabul ettiğine dair verilerin endişe vericiliğini vurgulamaktadır. "İşkenceye Onay" (26.Haz.08), "Insan Hakları Yok Ediliyor" (10.Ara.08), "Unutulan Insanlık” (10.Ara.10), "İşkence Artıyor mu?" (08.Kas.11), "Bilet Satana 13 Yıl Hapis" (02.Şub.12), "Sembolik Yürüyüşe Gözaltı” (24.Eki.12), "Açlık Grevlerinin 61. Gününde Başbakan Erdoğan'dan Aynı Sözler: Hala 'Şov' Diyor” (12. Kas.12), "Hapiste Büyüyorlar" (16.Mar.10), "Keyfi Cezalar Veriliyor" (05.Ağu.10) haberlerinden ve bu haberlerde kullanılan "Türk halkı teröristlere belli oranda işkence yapılmasını savunuyor", "Türkiye, Dünya Insan Hakları Günü'nü bu yıl da ihlallerle dolu bir karneyle karşıladi", "Tutukevlerinde yaklaşık 2 bin 900 çocuk var. Bunların 450 kadarı 'taş atanlar", "Türkiye, uzun tutuklulukların yaşandığı, öğrencilerin coplandığı, Romanların tecrit edildiği, Müslüman olmayanın mezardan çıkartıldığı bir dönemde Insan Hakları Günü'nü kutluyor", "iktidarın 'sıfır tolerans' söylemine karşın TïHV'ye 10 ayda 460 başvuru" ifadelerinden de anlaşılacağı üzere hem Türkiye'de yaşanan insan hakları suçlarına değinilmiş hem de verilen bazı cezaların çok uzun ya da gereksiz olduğuna vurgu yapılmıştır. "Suçları Grup Yorum konseri için çalışmak, Kadınlar Günü'nde yürümek, katliamlara tepki göstermek" ifadesi ile yer verdiği "Bilet satana 13 yıl hapis" sürmanşet siyah başlıkla verdiği haberde 'böyle adalet olmaz' ifadesini öne çıkaran gazete 2011 'de yaşanan hak ihlallerinin artışına da dikkat çekmiştir. "Unutulan Insanlık' adlı haberinde ise Türkiye'nin dört bir yanından gelen insan hakları ihlalleri haberleri ile insanlık onurunun zedelendiği yönünde ifadeler kullanmıştır. Türkiye İnsan Hakları Vakfı'nın yaptığı araştırmanın verilerinin kullandığı haberde "Türkiye'de, 28 kişi yargısı infazdan, 9 kişi faili meçhul cinayetten yaşamını yitirdi. Ayrıca 70 kişi linç girişiminden yaralandi" örneklerini vererek hak ihlallerine dikkat çekmiştir. Özetle gazetenin insan hak ve özgürlüklerine karşı duyarlı olduğu gözlemlenmektedir. Türkiye'deki insan hakları ihlallerine dikkat çekerek verdiği haberlerde öne çıkarılan en büyük nokta polis şiddeti ve gözaltı sürecidir. Bu tür haberleri iktidara karşı muhalif düşünceyle birleştiren gazete hak ihlallerinin ve işkencenin normalleştirilmesi sürecine karşı duyarlı bir tutum sergilemiştir.

Haklar konusunda Cumhuriyet gazetesinin haberlerinden ortaya çıkan diğer bir tema siyasi hakları da kapsayan demokrasinin ve meclisin ele alınışı şeklidir. Toplumsal eylem hareketlerine sıklıkla yer veren gazete siyasi seçimlere de önem vermiştir. Ancak TSK mensuplarının özellikle laiklik vurgusunu yaptığı konuşmalara dikkat çeken gazete "Askerden Açıklama" (28.Nis.07) sürmanşeti ile verdiği ve kamuoyunda "e-muhtıra" olarak adlandırılan 27 Nisan açıklamalarını tam metin olarak yayınlamıştır. Haberde bu açıklamadaki "Genelkurmay: TSK taraftır ve laikliğin savunucusudur. Gerektiğinde tavrını açıkça ortaya koyacaktır", "Başta laiklik olmak üzere, temel değerleri aşındırmak için bitmez tükenmez bir çaba içinde olan bir kısım çevreler", "Atatürk'ün anlayışına karşı çıkan düşmandır" ifadelerini ön plana çıkararak bu açıklamayı siyasi bir söylem olarak nitelendirmiş ve kendi ideolojik yapısı çerçevesinde olumluyan bir haber yapmıştır. Seçim ile ilgili haberleri genellikle "Geleceğimiz lçin Sandığa" (22.Tem.07), 
"Demokrasi ve Özgürlük Için Sandık Başına" (12.Haz.11), "Demokrasi lçin Sandığa" (12.Eyl.10) ifadelerini kullanarak veren gazete sandığın demokrasi için gerekliliğine vurgu yapmıştır. Seçim barajı ile ilgili olarak seçimler sonrası sandalye dağılımına çok fazla dikkat çekmeyen gazete genellikle hükümet ve muhalif partilerin başarı ve başarısızlıkları üzerinde durmuştur. "DTP Kapatıldi" (12.Ara.09) adlı haberde mahkemenin verdiği karardaki ifadelere yer veren gazete bir hukuk profesörünün de "Kararın ardından Kürt açılımı projesinin yürütülmesinin zorlaşacağı" yönündeki ifadesine yer vererek ve Adalet ve Kalkınma Partisi'nin kapatılması için açılan davada hukuki süreci takip edip parti kapatmanın demokratik bir sorun olup olmadığı tartışmalarına yer vermeyerek parti kapatmayı sadece siyasi bir olay olarak tartışmıştır. "Küçük Partileri Eritiyor: AKP Büyük Oynuyor" (14.Tem.12) adlı haberinde Erdoğan'ın HSP ve BBP'yi kendi partisine katmaya planladığını "sürecin altında 2014'te başkanlık ya da cumhurbaşkanlığı hesaplarının yattığı" yorumuyla vermiştir. Ayrıca "Bütün Saha Benim" (18.Ara.12) başlıklı haberiyle de "Başbakan Erdoğan kuvvetler ayrıı̆ıının engel olduğunu belirterek denetimsiz iktidar istiyor" ifadelerine yer vermiş her görüşü içine alan büyük partileşmenin yaratacağı iktidar sıkıntısına değinerek kuvvetler ayrılığının korunması gerektiğine dikkat çekmiştir. Gazete genel olarak meclis haberlerini siyasi partiler üzerinden değerlendirmiştir. Seçimlerin demokrasinin sac ayaklarından biri olarak görse de mevcut seçim sistemi üzerinden parti başarısı ve başarısızlığına değinen haberler yapmıştır. Bunun yanında bu haberlerde sıklıkla çok güçlenmiş bir yürütme organının kuvvetler ayrılığı ilkesini zedeleyici görüşüne vurgu yapılmaktadır.

Gazetenin haklar konusunda ele aldığı bir başka tema sosyal hakların temsilidir. Bu temada ortaya çıkan ilk vurgu ekonomik büyümenin ve sosyal güvenlik açığının çalışana olumlu bir şekilde yansımadığı ve çalışanın haklarının kısıtlanmaya çalışıldığıdır. "AKP'nin Sosyal Güvenlik Reformu diye sunduğu değişiklikler tüm kesimlerin hakkını buduyor: Hak Gaspının Adı Reform" (17.Kas.07), "Sosyal Güvenlik Açığı Korkutucu” (10.Eki.10), "12 Eylül yerinde duruyor: Sendikal Haklar Yok” (24.Eki.10), "Tamgün uygulaması üniversite hastanelerini vurdu, öğrenciler ve hastalar zor durumda: Hastaneler Tıkandi" (24.Eyl.11), "Grevsiz Toplu Sözleşme Yasası Gündemde" (30. Oca.12) gibi haber başlık ve girişlerine yer veren gazete hükümetin sosyal güvenlik ve sağlık politikalarını çalışan/maaşlı gözü ile değerlendirmiştir. "Sadaka Devleti" (11. Oca.08) manşetli haberinde sosyal devletin yeni yasa tasarısıyla yok olacağını dile getiren gazete "AKP hükümetinin hazırlattığı anayasa taslağında sosyal devletin önemli simgesi olan sağlık ve sosyal güvenlik hakları, tek bir maddeye indirgeniyor. Taslağın gerekçesinde asıl niyetin sosyal devletten liberal devlete geçiş olduğu satır aralarına gizlenip, sosyal yardıma vurgu yapılarak "hak" yerine "iane", "sosyal devlet" yerine "sadaka devleti" anlayışı egemen kılınmaya çalışılıyor" ifadelerine yer vermiştir. Benzer bir şekilde "Emekçi 3 Hafta Aç" (15.Eyl.08) manşetli haberinde KESK'in belirlediği verilere göre açlık sınırının altında maaş alan kamu çalışanlarına "bir kamu emekçisi ayın ancak 7 gününü yoksulluk sınırında, 23 gününü ise açlık sınırında geçiriyor", "Hükümetin verdiği maaşla 4 kişilik bir aile ayın sadece 7 günü 'insanca' yaşayabiliyor" ifadeleri ile dikkat çekmiştir. İkinci ön plana çıkardığı vurgu ise çalışma koşullarının kötülüğü ve işçi güvenliğinin sorunları ile ilgilidir. Bu başlıkta ele alınan haberler genellikle işçi ölümlerinin iş kazası değil iş cinayeti olduğuna dair vurgu ile dikkat çekmektedir. İş güvenliği yasasının ve denetimsiz işyerlerinin olumsuzluğunu dile getiren gazete 
çalışma hayatı koşullarının da insanca yaşamaya yeterli olmadığını yine hükümeti eleştiren sözlerle dile getirmiştir. "İ̧̧veren Çarpıtıyor” (22.May.08), "İ̧̧ Yükü Memurları Öldürüyor” (18.Haz.08), "Gün Taşeronun Günü” (03.Oca.11), “Çok Fazla Çalışıyoruz” (01.May.11), "Yaşam Ince ‘Dal'ın Ucunda” (06.Eki.11), "Işçiye Ölüm Düştü” (05.Nis.12), "3 Saatte 2 Iş̧̧̧i Ölüyor" (14.Ağu.08), "Taşeronlarla Çok Can Yanar" (20.May.10), "Kârınız Batsın" (13.Mar.12) başlık ve manşetiyle duyurduğu haberlerde "Tuzla'da önlem almak yerine sorumluluktan kaçıyorlar", "Vergi dairelerinde 7 kişi yaşamını yitirdi", "Kamuda çalışanların yarıdan fazlası güvencesiz; kadrosuz çalıştırma ağırlık kazandi", "Sömürüde önlerdeyiz", "Zonguldak'taki özel maden ocaklarında işçi yok pahasına çalışıyor", "İ̧ sağlığı ve güvenliği tasarısının yürürlüğe girmesi iki üç yılı bulacak", "Iş kazalarında vahim tablo", "Yüz milyonlarca liralık AVM inşaatında 11 işçi çadırda yaşamını yitird»" gibi ifadelere yer vererek işçilerin çalışma koşullarının kötülüğünü, güvencesizliğini ve taşeron firmaların yarattığı sıkıntıyı dile getirmiştir. Üçüncü vurgu işsizliğin Türkiye'de önemli bir sorun haline geldiğidir "TGS Araştırması: 5 Kişiden 1" İşsiz" (16.Tem.07) "İşsizlikte de Uçurum Var" (23.Ara.09), "Işsiz Sayısı 4 Milyon 988 Bin: Yüz Bin Seçmen Daha İşsiz Kaldı"(16.May.07), "İşsize Umut Oldular" (27.Nis.09) gibi haberlerle dikkat çektiği işsizlik konusuyla ilgili olarak hemen her ay verdiği işsiz sayısı oranlarını sosyal haklar açısından değerlendiren gazete işsizlikle mücadele konusunda hükümetin gerekli adımları atacak bir ekonomik plana sahip olmadığını vurgulamıştır. "Işsizlikte de uçurum var” başlığı ile verdiği haberde Türkiye'nin Doğusu ile Batısı arasındaki eşitsizlikte işsizlik boyutunun benzer şekilde adil olmadığını dile getiren gazete Türkiye'deki işsizliğe vurgu yaptığı haberde Doğu illerinde bu artışın daha fazla olmasını "ürkütücü" olarak nitelemiştir. "İşsize umut oldular” adlı manşetten verdiği haberde ise birçok işsiz kalmış insanın üniversite mezunları da olmak üzere güvenlik görevlisi olmak için kurslara yazıldığına dair vurguyu "Genç nüfustaki rekor işsizlik özel güvenlik mesleğine olan talebi yüzde 40 arttırdı" ifadesi ile duyurmuş ve Türkiye'de nitelikli iş gücü istihdamının yetersizliğine vurgu yapmıştır. Bu temada öne çıkan diğer vurgu gelir dağılımındaki adaletsizlik ve yoksulluktur. "Servet Uçurumu" (13.Kas.07), "Yurttaş Ekmeğe Talim Ediyor" (21.Tem.08), "Türkiye'de 4 Çocuktan 1"i Yoksup' (25.May.07), "Sadaka Ekonomisi" (04.Oca.09), "Yoksul Daha Yoksup' (01. Mar.11), "Yoksulluk Kıskaci" (10.Ara.12) gibi haber ve manşetlerle dikkat çektiği bu konuyu "Bankalardaki mevduatın yüzde 90'ı yüzde 3.4'lük kesimin elinde", "Alım gücü düşüyor", "TÜIK'e göre gelir dağılımındaki adaletsizlik katlanarak büyüdü. Yurttaşların yarısı giysi bile alamıyor", "Türkiye'nin 67 kenti düşük ya da orta gelir düzeyinden yukarı çıkamıyor' ifadeleri ile destekleyen gazete Türkiye'de yaşanan yoksulluğun sosyal haklarla ilgili bir sorun olduğunu ve sadaka ekonomisi politikasıyla çözülemeyeceğine vurgu yapılmıştır. Ayrıca Türkiye'deki gelir dağııımı adaletsizliğine yaptığı vurguyla da zengin fakir arasındaki uçurumun sosyal adaletsizlikten kaynaklandığını belirtmiştir. Sosyal haklar temelinde öne çıkan bu temada gazetenin yoksulluk, işsizlik ve gelir dağılımı adaletsizliğine dikkat çektiği gözlemlenmektedir. Tüm bu sorunların ekonomik problem olmaktan çok sosyal haklar çerçevesinde incelenmesine dair vurgunun yapıldığı haberlerde gazete devletin ekonomi politikasının yardımlaşma üzerine kurulu olmasını sadaka ekonomisi olarak nitelendirmiştir.

Vatandaş hakları üzerine yoğunlaşan bu konunun öne çıkan diğer teması kadın haklarıdır. Cumhuriyet gazetesi kadına uygulanan şiddeti münferit haberlerle çok 
az ana sayfasına taşımış genellikle bu konuyu olgusal olarak ele almıştır. Bu konu üzerine yapılan ilk vurgu kadının toplumda gördüğü şiddet ve mağduriyet ile devletin kadını korumadaki politikasının olgusal boyutudur. Burada kadının namus, töre ve şiddet yüzünden mağduriyetine dikkat çeken gazete "Aile lç̧i Şiddet Artıyor" (08. Haz.09), "BM'den Türkiye Raporu: 10 Kadından 4'ü Şiddet Görüyor" (09.Mar.10), "20 Bin Kadın 'Namus' Kurbanı” (08.Eyl.10) gibi haberlerle kadına karşı șiddetin nedenlerini ve boyutlarını ortaya koymaya çalışmıştır. Gazete devletin kadını korumadaki uygulamalarını da yetersiz bulmaktadır. "Türkiye'nin Ayıbı" (20.Mar.10) adlı haberde “Devlet kadını koruyamıyor. Son 12 günde 10'dan fazla cinayet işlend?", “işsizlik ve ekonomik sıkıntıların kadına şiddeti arttırdığını belirten uzmanlar, kadınların korunabilecekleri merkezlerin sayısının çok az olduğunu, devletin de kadını yeteri kadar koruyamadığını vurguluyor" ifadeleri ve "iki maddeyle kadın korunmaz" (27. Ara.10) adlı haberde Aile Mahkemesi yargıcının "Sistem kadını korumada sınıfta kaldı. Iki maddelik 4320 sayılı yasayla cinayetler önlenemez. Yasa çok önemli ve devrim niteliğinde olsa da önemli eksikliklere sahip" sözlerine dikkat çekerek yasanın yetersizliğine vurgu yapmıştır. Kadınların kamusal alanda ve iş hayatındaki yeri bu temada öne çıkan ikinci vurgudur. "Kadın Çalışan Sayısında Avrupa Sonuncusuyuz" (19.May.10), "Siyasette de Kadının Adı Yok" (08.Mar.09), "Krizin Faturası Kadına" (15. Ara.08), "Kadınsan Evinde Otur" (11.Tem.09), "Kadın Çalışanın Kayıtta Adı Yok" (17. Kas.10), "Meclis'te Yoklar: Kadınlar Siyasal Haklarını İstiyor" (05.Ara.10), "Ev Issçilerine Insanca Iş Çağrısı" (12.Haz.11), "Ayrımcılık Her Yerde: Kadın Diye İşten Çıkarıldı" (02. Eyl.11) gibi haberlerle ön plana çıkardığı durum kadınların çalışma hayatında ve siyasette yeterince var olmadıklarına dair olumsuzluğun dile getirilmesidir. "Siyasette de Kadının Adı Yok" adlı haberde kadınların siyasette yer alması ve seçimlerdeki adaylıkları ile ilgili sayısal veriler veren gazete “Dünya, 8 Mart Kadınlar Günü’nü kutlarken, Türkiye, siyasette kadının yeri açısından sınıfta kalan bir tablo sergiliyor. 3 bin 500'e yakın belediyeden yalnızca 17'sinde kadın belediye başkanı bulunuyor. Kadın belediye başkanlarının oranı yüzde 0.56 'da kalırken, 550 milletvekilinden ise yalnızca 50'sini kadınlar temsil ediyor. Kadın milletvekili oranı yüzde 10'u bile bulmuyor' ifadesini kullanarak kadının siyasette var olmamasının yarattığı dengesizliği sayısal verilere dayandırmıştır. Benzer şekilde "Kadın Çalışan Sayısında Avrupa Sonuncusuyuz" başlıklı haberinde de bir araştırma sonucuna dikkat çeken gazete "kadınların işgücüne katılamamasının işsizlik oranını tetiklediğı" şeklindeki yorumla kadınların işgücünde istihdamının az olmasını işsizlik vurgusuyla dile getirmiştir. Bu temadaki üçüncü vurgu kadın hareketleri ve eylemleridir. Gazete 8 Mart Dünya Emekçi Kadınlar Günü'nü her defasında haberleştirmiş ve kadınların toplumdaki sıkıntılarını dile getirmiş, kadınların eylemlerine yer verilmiştir. Ayrıca kadınların kürtaj ve sezaryenle ilgili yaptıkları eylemler ile kadına karşı şiddet ve taciz haberleri de sıklıkla gündeme gelmiştir. Bu haberlerden bazılarına değinecek olursak örneğin "Kadınlar Alanlarda" (09.Haz.12) adlı haberde "AKP hükümetinin kürtajı yasaklama girişimi eşzamanlı eylemlerle protesto edild?" şeklinde fotoğraflı bir haber yapan gazete kadınların "Kürtaj haktır, Uludere katliam”, "AKP elini bedenimden çek” gibi sloganlar attığına vurgu yapmıştır. "Alanları Doldurdular" (09.Mar.09) adlı haberde ise "8 Mart Dünya Emekçi Kadınlar Günü’nde kadınlar cinsel, ulusal, sınıfsal sömürüye, yoksulluğa, gericiliğe ve ezilmeye karşı yurt genelinde alanlara çıktı. Haklarını savunmak için buluşan kadınlar İstanbul Kadıköy'de 
düzenlenen mitingde 8 Mart'ın ücretli izin ve resmi tatil olmasını istediler' ifadelerine ve ellerinde döviz taşıyan kadınların fotoğraflarına yer vererek kadınların eylemine destek veren bir haber yapmıştır. Özetle Cumhuriyet gazetesi kadınların haklarını hem şiddete uğrayan kadınlar hem de kamusal alanda, siyasette ve istihdam açısından yeteri kadar yer almayan kadınlar olarak dile getirmiştir. Türkiye'de kadın eylemlerini daha çok taciz, cinsel istismar ve kürtaj üzerinde yoğunlaştıran gazete bu eylemlerdeki kadınların sosyal haklar vurgusuna da değinmiştir. Gazete bu tutumuyla kadınların kamusal alanda daha fazla yer alması gerekliliğine de vurgu yapmıştır.

\subsubsection{Hürriyet Gazetesine Yönelik Söylem Analizi}

Hürriyet gazetesinin ana sayfasındaki haberler incelendiğinde vatandaşlık haklarına yaptığı vurgunun çok az olduğu gözlemlenmektedir. Haklarla ilgili haberler nadir de olsa siyasetçilerin gündemi üzerinden dile getirilmiştir. Haklar liberalizmin temel yapı taşlarından biri olan özgürlükler üzerinde ele alınmış, eşitlik ilkesine dair vurgular çok az sayıda kalmıştır.

Tablo 2. Vatandaşlık Hakları Eksenine Dair İncelenen Haber Sayısı- Hürriyet Gazetesi

\begin{tabular}{|l|c|}
\hline \multicolumn{2}{|c|}{ VATANDAŞLIK HAKLARI EKSENI } \\
\hline TEMALAR & INCELENEN HABER SAYISI \\
\hline Siyasi Haklar ve Demokrasi Anlayışı & 31 \\
\hline Sivil Toplum ve Sivil Toplum Örgütlerinin Temsili & 37 \\
\hline Sivil ve Sosyal Haklar ile Yoksulluğun Yeniden Üretimi & 66 \\
\hline Grev ve İşçi Eylemleri & 30 \\
\hline Şiddet Gören Kadınlar Üzerinden Kadın Hakları & 51 \\
\hline TOPLAM & $\mathbf{2 1 5}$ \\
\hline
\end{tabular}

Bu başıık altında karşımıza çıkan ilk tema siyasi haklar ve demokrasi anlayışıdır. Devletin küçülüp sadece güvenlik ve özgürlüklerin korunması yönünde etkin olmasını savunan liberal anlayışa uygun olarak Hürriyet gazetesi de parlamenterlerin kişi özgürlüklerini ve girişimciliği engelleyen tavırda olmasına karşı olumsuz bir duruş sergilemiştir. "Mahdum Teşhiste" (28.Tem.12), "Teşhisçi Terfi Etmiş"(30.Tem.12), "Vekile, Bana Dokun Hakk” (27.Ağu.07), "Meclis Tezkere Onlar Hamili Kart Derdinde" (18.Tem.07), "Sınırsız Iktidar Anlayışı Tehlikesi”(09.Eyl.08), "O şimdi ATO Üyesi Bir Tüccar” (24.Nis.08) gibi haberlerle başlıklarını kullanan gazete "Mahdum Teşhiste" adlı sürmanşetten verdiği haberde Hatay milletvekilin oğlunun tartıştığı polislerle ilgili karakolda teşhis fotoğrafını yayınlayan gazete milletvekili oğlu için "tartıştığı polislerin şüpheli gibi teşhis ettirmesi tartışmalara yol açtı" ifadesini kullanmış, milletvekili oğluna da "mahdum" diyerek Osmanlı dönemindeki paşalık sistemine gönderme yapmıştır. "Sınırsız İktidar Anlayışı Tehlikesi” başııkı haberde ise Yargıtay Başkanı'nın adli yıl açılış törenindeki konuşmasından "Her organ yetki ve görevlerini Anayasa, yasa ve hukukun üstünlüğü kurallarına uygun şekilde kullanmak zorundadır” ifadesini ön plana çıkararak hükümetin diğer organlar üzerindeki etkisini eleştiren bir haberi ana sayfasına taşımıştır. Bu tema üzerindeki diğer bir vurgu seçimlerle demokrasi arasındaki ilişkiye kurduğu bağdır. 
"Son Sözü Oyla Söyle” (12.Eyl.10), "Seçebilmek Ne Güzef' (12.Haz.11), “Aysun’a Inat AKP Çobani” (14.Nis.08), "Biz Bir Aileyiz” (22.Tem.07), "Türkiye'nin 13 Gerçeği Seçmen Yerel Seçimde Şu Mesajı Verdl” (31.Mar.09) gibi haberlerde öne çıkan nokta seçme ve seçilme hakkının önemi ve herkesin bu hakkı kullanmadaki eşitliğine yapılan vurgudur. "Biz Bir Aileyiz" adlı seçim gününde yazılan yazıda "ayrılıklarımız olsa da biz aynı hedeflere kilitlenmiş, aynı ülküleri paylaşan dev bir aileyiz. Bugünkü seçimi de bundan öncekiler gibi kardeşlik, birlik ve beraberlik duyguları içinde gerçekleştireceğiz" diyerek aslında seçimlerden huzur ve birlik çıkması gerekliliğine vurgu yapılmıştır. Bu yazıda hepimiz aynı amaçlara sahibiz bunun dışına çıkan bizden değildir vurgusunu yaparak öteki olarak çatışmacı fikirde olanları göstermiştir. Ayrıca bu yazının alt metninde sonuçlar ne olursa olsun sandığa saygı göstermek ve bu birliği kabullenmek gerekliliği vurgulanarak istikrarın sağlanması gerekliliğine dikkat çekilmiştir. Bu temadaki diğer vurgu siyasi haklara getirilen kısıtlamaların istikrarı ve demokratik düzeni bozacağı yönündeki görüşüdür. "Parti Kapatma Kabul Edilemez" (17.Mar.08) başııkı haberde TÜSIAD Başkanının "TÜSIAD açıklamasında siyasi partilerden, Türkiye'yi, kutuplaşmaları körükleyen bir siyasi atmosferden uzaklaştırarak, uzlaşı ve refah projeleri üreten bir siyaset ortamına taşımalarının beklendiği vurgulandı" sözlerine yer veren gazete "Peki Biz Bu Stresi Niye Yaşadık" (22.Nis.11) adlı haberde ise YSK'nın bazı milletvekili adaylarının adaylıklarının iptal edilip sonra kararın geri alınmasını değerlendirirken Ertuğrul Kürkçü'nün “Keşke vakitlice ve doğru bir şekilde karar verilebilseydi, Bu süre içerisinde insanlar hayatlarını kaybetmeselerdi, en çok bunun için canımız yanıyor" şeklindeki sözlerine yer vererek olaylarda çıkan kaos nedeniyle sorumlu tuttuğu YSK'yı eleştirmiştir. Gazetenin bu tema altında ele alınan haberlerde işlediği temel düşünce seçimlerin demokrasi için çok önemli olduğudur. Gazete için kaos ve çatışma istikrara gelebilecek en büyük zarar olduğundan ve düzeni bozucu etkisi nedeniyle istenmeyen bir durum olarak gösterilmiş, seçimlere saygı gösterilmesi gerekliliği vurgulanarak meclisin üstünlüğü dile getirilmiştir.

Vatandaşlık hakları ekseninde öne çıkan diğer tema sivil toplum ve sivil toplum örgütlerinin temsilidir. Gazetenin en çok gündeme getirdiği sivil toplum kuruluşu, TÜSiAD'dır. Bunun dışında birçok işçi sendikası olumsuz haberlerle ana sayfaya taşınmıştır. "7'nci Kata Silahla Çıkıp Vurdu" (06.Eki.09), "Yol Işste Yolsuzluk” (05.Eyl.08), "Bayram Maaşı" (12.Eyl.08), “'ş̧çi Parasıyla 5 Yıldızlı Gezi” (10.Kas.08) gibi haberlerle sendikalar genellikle yolsuzluk ya da olumsuz konularla haber olmakta ve manşete çıkmaktadır. "Yol Işste Yolsuzluk" adlı haberde "Ayda net 9 bin YTL maaş alan Barın ile ayda net 8 bin YTL maaş alan yedi yönetim kurulu üyesi, yılın 365 günü Ankara dışında görevdeymişler gibi 'tam harcırah' aldı. Başkan ve yöneticiler, dört aylık ücretleri tutarında ikramiye, izin parası ile yüksek miktarlarda 'temsil ödeneği' aldılar. Barın'a bunlara ilave olarak, yıllık ücretli izin süresinin ücreti de ödend?" ifadelerini kullanan gazete, "İşçi Parasıyla 5 Yıldızlı Gezi" adlı haberde de "YOL - iş Sendikası, Içişleri Bakanı Beşir Atalay, Bakan'ın seçtiği 12 vali, bürokratlar ve bunların eş ve çocuklarından oluşan 300 kişilik bir heyeti, Girne'de 5 yıldızlı bir otelde 4 gün 4 gece ağırlayacak' ifadelerine yer vererek sendikaları sendika faaliyetleri dışındaki bir olaydan dolayı haberleştirmiş, bunu yaparken de aslında sendika başkanlarının işçinin hakkını yediğini vurgulayarak işçi sendikalarını olumsuzlamıştır. Sendika haberlerine pek fazla yer vermeyen gazetenin böyle olaylara ana sayfasında yer vermesi işveren ile işçi sendikaları arasındaki 
ilişkide bir tutum ve taraf takındığını göstermektedir. Gazetenin idealize ettiği sivil toplum örgütü daha liberal temellidir. 2008 yılında başlattığı bir çalışmayla gazetenin vatandaşları okur meclisine davet ettiği görülmüştür. Bu meclisin kurulmasından sonra Anıtkabir'e gidip çelenk koyulması ile ilgili fotoğrafın kullanıldığı "Hürriyet Okur Meclisi" (04.Ara.08) sürmanşetiyle duyurduğu haberde "Hürriyet Okur Meclisi'nin ilk toplantısında, özellikle kadın üyelerin spor sayfalarında Anadolu takımlarına da yer verilmesini istemesi ve spora olan ilgileri dikkat çekti. Üyelerin büyük bölümü, Hürriyet'in başlattığı "Aile lçi Şiddeti Son" ve "Hürriyet Insan Hakları Treni" gibi sosyal sorumluluk projelerinin önemini vurguladılar" şeklinde belirttiği ifadeden de anlaşılacağı üzere gazete Türkiye'deki gazetecilik sorunlarının sosyal sorumluluk projeleri ve futbol haberleri ile çözüleceğine dair inancın okur tarafından savunulduğunu belirterek liberal ve anaakım bir pozisyonda olduğunu göstermiştir. Bu temadaki diğer vurgu gündeme getirilen sivil toplum eylemleridir. Çok kısıtlı sayıdaki sivil toplum eylemini gündeme getiren gazetede dikkat çekici birkaç başlık şu şekildedir: Cumartesi Annelerinin eylemi için "Acılar Yaşlanmadı" (25.Kas.12), Tutuklu Gazeteciler için yürüyen gazeteciler için “Meslektaşları lçin Yürüdüler” (04.Mar.12), ÖSYM’nin şifre skandalları ile ilgili gündeme gelen öğrencilerin "Biz Tatmin Olmadık Protestosu" (11.Nis.11), Sivas Davası zaman aşımı için "Adalet Miting”"(01.Nis.12), Hukukçuların yargı bağımsızlığı için yaptıkları yürüyüş için "Yargıya ve Ülkene Sahip Çık” (19.Kas.09) başlıklarını kullanmış, eylemlerle ilgili bilginin verildiği haberlerde yorumlara çok fazla rastlanmamıştır. "Söylem Eylem: IMF Defol" (07.Eki.09) adlı haberde ise "IMF toplantısında, liderler yoksullukla mücadele edilmesini savunan konuşmalar yaparken, dışarıdaki göstericiler ise yoksulluk adına çeşitli eylemlerle IMF'ye savaş açtılar" diye eylemcileri eleştiren bir tutum takınan gazete her türlü çatışmanın ve protestonun uzağında, çözüm arayışlarını yasal kurum ve kuruluşlara bırakan bir düzen arayışı içine girmiştir. Bu tema altında incelenen haberler doğrultusunda Hürriyet gazetesinin sivil toplum örgütleri olarak daha çok liberal niteliklere sahip yapılaşmayı savunduğunu söyleyebiliriz. Sendikal haberlerin genelde olumsuz ele alınması ve STK'lara çok fazla yer verilmemesi bununla birlikte TÜSIAD'ın çok sık ana sayfada yer alması ve söylemlerinin olumlanması gazetenin bağlı olduğu kurumun bu dernekte etkin rol alması ile açıklanabilir. Gazetenin çok ses getirmeyen siyasi gündemde yer almayan kuruluşlara ana sayfasında yer vermemesi sivil toplumu ele alış açısından gazetenin eksikliklerini göstermektedir.

Bu başlık altında değerlendireceğimiz diğer tema gazetede çok fazla yer almayan grev ve işçi eylemleridir. "Görülmemiş Tepki Yasaya Fren Koydu" (15.Mar.08) adlı haberde işçi sendikalarının hükümetin Sosyal Güvenlik Tasarısı'nı geçirmemek için yaptığı ve "son 17 yılın en büyük sendika eyleminde yüzbinler sokağa ind?" ifadesi ile değerlendirmiş "AKP sosyal güvenlik tasarısını yeniden gözden geçirmek için frene bastı" diyerek sendikal hareketin hükümet üzerindeki gücüne vurgu yapmıştır. Ancak gazetenin diğer işçi eylemlerini çok fazla gündeme getirmemesi veya polis şiddetini ön plana çıkararak ifade etmesi bahsedilen bu haberin bir istisna olduğunu göstermektedir. Gazete "Oğlum da Ölmesin diye Eylemdeyim" (30.Oca.10), "Tekel İşçilerine Sert Müdahale" (18.Ara.09), "Memura da Biber Gazi" (24.May.12), "179 Sefer Iptal” (30. May.12), "Elimizde Net Görüntüler Var" (18.Haz.12), "Rengarenk Uyarı" (26.Kas.09), “Eylem Günü” (27.May.10) gibi haberlerle grev ve mitinglerde biber gazı ve şiddete dikkat çeken haberler yapmıştır. "179 Sefer İptal” adlı haberde "Hava-iş Sendikası'na üye 
Türk Hava Yolları kabin memurlarının iş bırakma eylemi 179 seferin iptal edilmesine yol açtı. THY, iptal edilen seferlerin dış hat yolcularını otellere yerleştird?' ifadesini öne çıkararak haberleştiren gazete, grevin yarattığı sıkıntıya vurgu yaparak haberi grevin yapılış amacından uzaklaştırmış, okuyuculara da grevlerin yarattığı sıkıntılar vurgulanarak destek gösterilmemesi yönünde telkinde bulunulmuştur. Benzer bir şekilde gazete "1 Mayıs İşçi ve Emekçiler Bayramı" için de günün anlamına dair bağlamdan uzak haberler yapmıştır. Herkesi sağduyuya davet eden gazete işçi sendikaları ile işverenler arasında çatışmanın çıkmaması adına sağduyu mesajları vermiştir. Polis şiddetini de kınayan gazete valilik ile sendikalar arasındaki Taksim'de eylem yapma tartışmalarından da rahatsız olmuştur. "Aman Sağduyu" (01.May.08), "1 Mayıs Polis Devleti” (02.May.08), "Taksim'de Makul Sayı Restleşmesi” (01.May.09), "31 Yıl Sonra Taksim", "Sapan Timi İş Başında" (02.May.09), "Naklen 1 Mayıs" (02.May.12), "Kes Yolu Ver Gazi" (02.May.07) gibi haberlerle hem bayramın sağduyu ve çatışmadan uzak kutlanılması gerekliliğine vurgu yapmış, hem de bayramdan daha çok polis ve bayrama katılan işçiler arasındaki çatışmayı öne çekerek ana konudan uzaklaşmıştır. Bu haberlerinden en dikkat çekici olanlarından biri "Naklen 1 Mayıs" haberidir. Gazete tam sayfa haber yaptığı 1 Mayıs Bayramı ile ilgili olarak haber girişinde yazdığı "Yüzlerce fotoğraf, onlarca haber, çok sayıda video-röportaj ve saat 08.30'dan itibaren yedi ayrı noktadan kesintisiz canlı yayın... Türkiye 1 Mayıs'ı dün internette Hürriyet Dünyası'ndan takip ettr' ifadesi ile aslında önemli olanın bayram değil Hürriyet gazetesinin başarısı olduğunu vurgulamıştır. Gazete işçi eylemleri dışındaki miting haberlerini de polis şiddetiyle birlikte sunmuştur. "Adalet Tam Gaz" (14.Ara.12), "Protestocuların Görüntüleri Elimize Ulaştı" (19.Oca.11), "İzmir'de Polisten Sert Müdahale Su, Boyalı Su, Yetmedi Gaz" (29.Mar.12), "Yine Aynı Ayıp" (11.Şub.11) gibi haberlerde polisin müdahalesini yanlış bulan ifadelerde bulunmuştur. Bunun yanı sıra bazı miting haberlerini ise olumsuz bir dille vermiştir. Metin Lokumcu'nun öldüğü Hopa Mitingini “Konvoya Taşı Saldırı" (01.Haz.11) başığı ile duyuran gazete "Başına taş isabet eden koruma polisi otobüsten düştü” ifadesi ile haber girişini sunmuştur. Metin Lokumcu'nun ölüm haberini ise daha önemsiz bir şekilde sunan gazete olayları "protestocu grup polislere kaldırım taşlarıyla saldırdı, polis tazyikli su ve biber gazı kullandı. Emekli öğretmen Metin Lokumcu, kalp krizi geçirip yaşamını yitirdr' şeklinde bildirmiştir. Gazete mitingi yapanların şiddet kullandığına dair vurgu yaparak ölümü önemsizleştirmiştir. "Mitinge Anarşi Bulaştı" (30.Kas.08) adlı haberde ise "DiSK ve KESK tarafından işsizliğe, yoksulluğa zamlara karşı Ankara'da yapılan barış ve demokrasi mitinginde üzerlerini aratmak istemeyen 'Anarşist' adlı grup, polise taş yağdırdı' ifadesini kullanarak yine miting ve anarşi, saldırganlığı bir arada kullanmıştır. Gazetenin bu eylemler için takındığı genel tutum ana konudan ve bağlam bilgisinden uzak haberler yapmasıdır. Olaylardaki şiddetin daha ön plana çıktığı eylemlerde polis baskısı eleştirilmiş, ancak grevlerin yapılış nedenlerine dikkat çeken haberlere çok fazla yer verilmemiş ya da ikinci planda bırakılmıştır.

Bu konu altında ele alacağımız diğer tema sivil ve sosyal hakların temsili ile yoksulluğun yeniden üretimidir. Gazete sosyal hakların temsili konusunda çok fazla habere yer vermemiştir. Çıkan haberler doğrultusunda gazetenin genel tutumu incelendiğinde devletin sosyal haklarla ilgili hizmetlerin yetersiz olduğu görüşünün öne çıktığı gözlemlenmektedir. “Kurtarma Rezaleti” (10.Şub.10) “45 Dakikada Bulunmaz mı” (05.Eyl.10), 
"Simav'da Deprem Sınavı Otur Sıfır" (21.May.11) gibi haberlerle yer verdiği ve devletin güvencesi altında olması gereken konularda devletin başarısızlığı vurgulayan gazete "Simav'da Deprem Sınavı Otur Sıfı" başlıklı haberde "Kütahya'nın Simav IIlçesi'nde önceki gece 23.15'te meydana gelen 5.9 büyüklügündeki deprem, yaşananlardan ders almadığımızı bir kere daha gösterdi. Depremin ardından 25 bin nüfuslu ilçeyle bağlantı kesildi, telefonlar çalışmadı, internete girilemedi. Kandilli Rasathanesi'nin sitesine de uzun süre ulaşılamadi" ifadelerine yer vererek Türkiye'nin hala bazı konulardaki geri kalmışlığına vurgu yapmıştır. "45 Dakikada Bulunmaz mi" manşeti ile verdiği haberde ise "Bostancı'da bisikletten düşen matematik profesörü 45 dakika sonra kaldırıldığı hastanede öldü. Sağlık Bakanlığı, gecikmeyi "2 ambulans adresi bulamadı" diye açıkladı" ifadesine yer vererek benzer şekilde Türkiye'deki sağlık ve sosyal güvenceye ait hizmetlerin başarısızlığını dile getirmiştir. Bir diğer vurgu yine çok az dile getirdiği sosyal güvenlik yasası ile ilgili gelişmelerde popülist bir yaklaşım benimsemiş olmasıdır. "Kadın Issçinin 5 Gün Sancısı" (05.Oca.10), "Doğum Sonrası 1 Yıl Gece Nöbeti Yok" (06.Şub.11), "Eşi Doğum Yapan Memura 5 Gün İzin" (23.Ağu.08), "Kiralık Iş̧̧̧i Geliyor" (26.Tem.12) gibi başlıklardan da anlaşılacağı üzere gazete çok fazla derine inmeyen ve daha yüzeyde kalmış konuları haber başlığı yapmayı tercih etmiştir. Gazete aynı zamanda işçi ölümlerine karşı da münferit bir tavır takınmış, işçilerin ölümündeki acıyı haber metinlerinde işçi güvenliği etiğinden daha sık vurgulamıştır. "9 Madenci Toprağa Verildi 10 Iş̧̧̧inin Cesedi Çıkarıldı" (13.Ara.09), "Maden onları cansız verdi Acı TüneII" (21.May.10), "İşte ölen madencilerden ağlatan öyküler" (21.May.10), "15 Dakika Önce Yapmayın Dedi” (13.Ağu.08), "Üste Bir de Para İstiyor” (18.Oca.10) gibi haber başlıkları ile işçi ölümlerine olgusal bakış açısı ile değil olaylar üzerinden giden bir tavırla yaklaşmıştır. Bu olaylardaki acıyı da ön plana çıkaran gazete "15 Dakika Önce Yapmayın Ded»" manşeti ile verdiği haberde "Tuzla'daki Gisan Tersanesi'nde başka bir test için gemide bulunan Fransız Loyd'u, kazadan hemen önce yetkilileri "Yapmayın. Canlı denekle test olmaz" diye uyarmış" ifadesi ile iş kazalarındaki sorumsuzluğa dikkat çekse de haberde ana sayfasına yansıttığı kısım olayın nasıl gerçekleştiği ile ilgilidir. Bu tema altındaki diğer vurgu yoksulluğun ve yardımlaşmanın ele alınış şeklidir. Gazete seçim dönemlerinde daha çok ortaya çıkan Belediye yardımları ile ilgili olarak da olumsuz bir tavır takınmıştır. "Buzdolapçı Valinin 3 Yıl Hapsi İstendi" (05.Oca.11), "Yozgat'ın Günahı Ne" (06.Şub.09), "Büyükşehir Savaşı" (20.Kas.08) manşetleri ile duyurduğu haberlerde "Tunceli'de seçime iki ay kala beyaz eşya dağıtımının bu ilden daha yoksul durumda olan 29 ilde, örneğin Yozgat'ta yapılmaması eleştirilere neden oldu", "Ankara Büyükşehir Belediyesi seçim öncesi bedava kömür dağıtımına hız verdi. Belediye doğalgaz kullanılan semtlerde bile bugüne kadar toplam 70 bin ton kömür dağıttı. Ihtiyacı olmayan vatandaşlar da bu kömürü satıyorlar" ifadeleri ile çok sert olmasa da eleştirel bir dille dağıtımı eleştirmiştir. Gazete yoksullukla ilgili olarak çok fazla habere yer vermemiştir. "Yoksulluk Yardımına Puan Sistemi" (19.Eki.11), "7 Milyon Yeşil Kart Iptal Edild?' (20.Oca.09), "7 Haneden Biri Yardım Alıyor" (22.Nis.09) haberleri ile hükümetin yoksullukla ilgili yaptığı düzenlemelere yer veren gazete "7 Milyon Yeşil Kart Ijptal Edildi” başııkı haberde Maliye Bakanlığı'nın kamu harcamalarına ilişkin incelemeleri doğrultusunda birçok alanda ortaya çıkan usulsüzlük iddialarında yeşil kart sahiplerine ait iddiayı ön plana çıkararak haberleştirmiştir. Gazetenin bu vurguyu haber başlığına taşıması ve haber metnini bunun üzerine kurması dikkat çekicidir. Haberde 
kullanılan “Maliye Bakanlığı'nın kamu harcamaları incelemelerinde, yeşil kartta büyük vurgun ortaya çıktı" ifadesi ise sosyal adaleti sağlama yönünde pozitif bir adım olarak nitelendirilebilecek bir uygulamadaki usulsüzlükleri ön plana çıkarılarak olumsuzlandığı görülmektedir. Gazetenin bu tür haberler haricinde yoksullukla ilgili yaptığı haberler genelde münferit olaylara dayanmaktadır. "Üniversiteli Ömer Herkesi Ağlattı" (25. Ağu.10), "Para Bulamadım Anneciğim" (07.Nis.10), "Keko’nun Drami” (11.Mar.10) gibi haberlerde yoksulluk gazetede olgusal bir sorun olarak algılanmadan haber malzemesi olarak kullanılmıştır. Böyle bir anlayış hem okuyucunun bahsi geçen insanlara karşı duygularını sömürmekte, hem de yoksulluğu okuyucular için ötekileştirmekte, ana konudan uzaklaştırmaktadır. Örneğin bir üniversite öğrencisinin inşatta çalışırken düşüp ölmesi gazete için "Üniversiteli Ömer Herkesi Ağlattı" anlamına gelmektedir. Haber değeri olan şey bir öğrencinin yurt ve eğitim masrafları yüzünden okuldan ayrılmak zorunda kalması ya da bir işçi olarak Ömer'in çalışma güvenliğinin sağlanamaması değil ailesinin ağıtları ve fakirliğidir.

Bu konu altında ele alacağımız diğer bir tema kadın haklarına yapılan vurgudur. Kadın gazetenin genelinde şiddet gören kadın olarak yansıtılmış ve gazete kendi deyimiyle "kadın konusunda taraf" olduğunu açıklamıştır. Aile içi şiddetin ve tecavüz olaylarının ayrıntıyla yer verildiği gazetenin kadın konusunda taraf olması da ironiktir. Gazetenin şiddet, tecavüz ve katliam haberlerini sansasyonel başlıklarla dile getirdiği gözlemlenmektedir. 3.sayfa haberleri olarak nitelendirilebilecek bu haberler, siyasi gündemin çok meşgul olmadığı zamanlarda genellikle manşet olarak karşımıza çıkmakta, mozaikleme tekniği ile de olsa şiddet görüntüleri okuyucuya iletilmektedir. Bununla birlikte kadınların öncelikli ve hatta tek sorununun şiddet olduğu düşüncesi ile hareket eden gazetede kadın eylemleri şiddet olayları dışında neredeyse hiç gündeme gelmemiş, gelenler de magazin boyutuyla verilmiştir. Kadın haklarının temsili konusunda öne çıkan ilk vurgu oldukça sık gündeme taşıdığı kadına karşı şiddet ve onun önlenmesi ile ilgilidir. "Şiddete Karşı Acil Yardım Hattı" (27.Eki.07), "Meclis’ten Kadına Yasa Armağanı" (09.Mar.12), "Kadına Karşı Şiddetin Cezası Artmalı" (26. Kas.11) gibi örneklerine rastlayacağımız kadınları şiddetten koruyan düzenlemelerle ilgili haberler dikkat çekmektedir. "Şiddete Karşı Acil Yardım Hattı" başlıklı haberde "Hürriyet Gazetesi, üç yıldır başarıyla sürdürdüğü "Aile Içi Şiddete Son” kampanyası kapsamında yeni bir proje başlattı" ifadesi ile kendi yaptığı projenin duyurusunu vererek bu konuda taraf olduğunu dile getirmiştir. Gazete "Kadına Karşı Şiddetin Cezası Artmalı" başlıklı haberde "Aile Içi Şiddete Son" konferansında konuşan AB Bakanı Egemen Bağış'ın, "cezaların artacağı mesajını vererek "Kadına şiddet insanlık suçudur. Cezası ağır olmalıdır ve hükümetimiz bunu sağlama çabasında" sözlerine yer vererek kadına şiddette "terörden daha fazla kurban" verildiğine dikkat çekmiştir. Ancak gazetenin kadına şiddet açısından bu duyarlı tutumu kadınların kamusal alanda temsili ile ilgili yaptığı haberlerle örtüşmemektedir. Her ne kadar kadınların kamusal alanda ve parlamentoda yer almasına vurgu yapan haberler yapsa da bu haberler kadına karşı şiddet kadar yoğun bir dille ve sıklıkta ana sayfada yer almamaktadır. "Kadın Kotası Uygulanmalı" (07.Nis.07), "Seçmen Kadın Aday Istiyor" (02.Nis.11), "Refahın Temelinde Eğitimli Kadın Var" (09.May.07), "Çalışan Annelerin Çocukları da Mutlu” (21. Ağu.10), "Hem Kariyer Hem Çocuk Mümkün" (15.Ağu.11) gibi haber başlıklarından da anlaşılacağı üzere bazen küçük de olsa kadınların kariyer yapmalarını destekley- 
en gazete daha çok kadınların siyasette yer alamamasına vurgu yapmıştır. "Seçmen Kadın Aday İstiyor" başlıklı haberde Kadın Adayları Destekleme ve Eğitme Derneği'nin (KADER)'in, KONDA'ya yaptırdığı araştırma sonuçlarına dikkat çeken gazete "Seçmen, adayın kadın olması halinde oy vereceği partiye ilişkin kararının güçleneceğini söylüyor" ifadesini ön plana çıkararak kadınların siyasette olmasının Türkiye'de büyük değişikliklere neden olabileceğinin altını çizmiştir. "Çalışan Annelerin Çocukları da Mutlu" adlı haberde ise bir araştırmanın verilerine dikkat çeken gazete araştırmanın "çalışan ve çalışmayan annelerin 3-5 yaş grubuna mensup çocukları arasında ruhsal açıdan fark bulunmadığını otaya koydu" sonucuna dikkat çekerek çalışan kadınların ailede problemlere neden olmayacağını vurgulamıştır. Gazetenin kadınlar konusunda yaptığı haberlerde kadın eylemlerine pek rastlanılmamaktadır. Özellikle 8 Mart Dünya Emekçi Kadınlar Günü'nde ve sonrasında genellikle ana sayfaya hiç haber taşımamıştır. Gazete bazen sadece "Kadınlar Gününüz Kutlu Olsun” ifadesine yer vererek bu günü önemli bir gündem maddesi olarak görmemektedir. Kadınların eylemleri genelde kısıtlı da olsa türbana karşı yapılan eylemlerle de dile getirilmiştir. "Kadınlar Meydanlarda" (03.Şub.08) başlıklı haberde kadınların Türban karşısında bir araya gelerek yaptığı mitinge dikkat çekmiştir. Kürtajın yasaklanmasına karşı da eylem yapan kadınlarla ilgili genelde küçük haberler yapan gazete "Kadına Kelepçe" (02.Haz.12) başlıklı haberde Bakanlık önündeki kürtaj eylemine polislerden sert müdahale geldiğini vurgulamıştır. Benzer amaçlı eylemlerde kullandığı "Kime Ne Yürüyüşü” (04.Haz.12) başlıklı haberde ve çocuk gelinlere ve şiddete karşı yapılan eylemde "Neşeli Ayaklar" (04.Mar.12) başlığını atarak küçük de olsa kadın eylemlerini dile getirmiştir. Gazete emekçi kadın haberlerine yer vermese de yine de idealize ettiği kadın tipi ekonomik anlamda güçlü ve liberal/kapitalist/modern dünyanın oluşturduğu koşullara ayak uyduran kadındır. Hürriyet gazetesinde bu kadın imajı genellikle iş kadınları arasından seçilmektedir. Özellikle TÜSIAD başkanının kadın olması başarılı kadın imajının bu model üzerinden çizilmesi ile vücut bulmuştur. Aile içi şiddetin kınandığı haberlerde yukarıda seçtiğimiz örnekler dahilinde "kan”, "işkence” "çaresiz kadın”, "çıplak ceset”, "kalbinden Bıçaklandı", "Parçalara Ayırmıştı" ifadelerine yer vererek hem bu şiddet ve taciz olaylarının normalleşmesini sağlamakta hem de bu olayları araçsallaştırarak haber malzemesi çıkarmaktadır. Şiddetin ayrıntılarıyla verildiği haberlerin yanında mağdur kadın fotoğraflarının yer alması aslında gazete "istemeden de" olsa şiddeti normalleştirmekte ve yaymaktadır. İlginç olan nokta gazetenin genel anlamda kadını şiddetle birlikte anmasıdır. İncelenen ana sayfaların çoğunda kadın temelli haberlerde kadın ya cinsel bir obje ya da mağduru canlandırmaktadır. Gazetenin bunun karşılığında kendi idealize ettiği kadın tipine uygun haberler aynı sıklıkta ana sayfada yer almamaktadır. Bir diğer nokta ise kadının toplum içerisinde eşit haklara sahip olduğu düşüncesinin ve çalışma hayatındaki varlıklarının gazete tarafından yok sayılmasıdır. Gazetenin en çok haber yaptığı diğer kadın imajı yukarıda da belirttiğimiz gibi cumhuriyetin ve laik düzenin koruyucusu olan kadındır.

\section{Sonuç}

Devlet; ideolojisi çerçevesinde oluşturduğu makbul vatandaşlık kurgusunu ve bu vatandaşlık anlayışının davranış kalıplarını vatandaşlarının, küçük yaşlardan itibaren içselleştirmesini hedefler. Feodal düzende tebaa olarak ortaya çıkan makbul 
olma durumu, siyasi iradeye ya da egemen güce boyun eğmekle ortaya çıkmaktadır. Sonsuz itaat ve bağlılığın söz konusu olduğu bu dönemde hiçbir şekilde düzeni sorgulamaya yer yoktur. Ancak Antik Yunan'ın erdemli vatandaşlık bilinci Ortaçağ'da tamamen unutulmamış, Rönesans ve Reform hareketleri ile tekrar gündeme gelmiştir. $\mathrm{Bu}$ harekelerin de içinde yer aldığı toplumsal değişme sonucunda mutlak iktidarın yavaş yavaş çözülmeye başladığı gözlemlenmiştir. Protestan Ahlak, Sanayi Devrimi ve Fransız İhtilali'nin bir sonucu olarak halk, mutlak iktidarın kırılmaz yapısında önemli bir kırılma yaratmış ve birey olarak var olduğunu göstermiştir. Her ne kadar bu devrimler burjuva sınıfının devrimleri olarak nitelendirilse de vatandaşlık hakları açısından önemli bir yere sahiptir.

Marshall'ın sistematikleştirdiği vatandaşlık hakları üç ana eksende toplanmaktadır: Sivil, siyasi, sosyal haklar. Bunlardan ilki sivil toplum kavramının gelişmesi ile ortaya çıkan temel bireysel haklar üzerinedir. Düşünce ve inanç özgürlüğü, düşüncenin özgürce ifade edilebilmesi özgürlüğü, mülkiyet ve sözleşme hakkı gibi temel haklardan oluşmaktadır. Siyasi haklar ise genellikle seçme ve seçilebilme özgürlüğü ile demokratik katılımı ifade etmektedir. Sosyal haklar ise refah devleti/toplumu ile ilgili olarak sağlık, eğitim ve insanca yaşama hürriyetini de içine alan ve diğer iki hakkın kullanımı ile gelişen bir niteliğe sahiptir.

Ele alınan haberler doğrultusunda vatandaşlık hakları konusunda en çok haberi yapan Cumhuriyet gazetesi ulusalcı sol ideolojiye yakın bir gazetedir. Neoliberal politikaların sıklıkla eleştirildiği gazetede özellikle işçi hak ve eylemelerinin sıklıkla temsil edilmesi tutarlı bir durumdur. Sivil toplum ve STK'ların genellikle olumlu temsil edildiği, toplumsal hareketlere dayalı eylemlerin haberleştirildiği gazetede; demokrasi ve milli egemenlik kavramları da sıklıkla işlenmiştir. Gazete özellikle sosyal haklar çerçevesinde okuyucu olan yurttaşa sivil olarak aktif olanların başarıya ulaşacağı mesajı verilmiştir. Gazetenin haklar çerçevesinde makbul gördüğü davranış, özgürlük, eşitlik ve demokrasi üzerine kuruluyken, toplumsal hareketlere katılan, eleştirel düşünebilen, cumhuriyetin değerlerine sahip çıkan, hükümet karşıtı olan yurttaşları olumlayıcı haberler üretmiştir. Bununla birlikte gazetenin hükümete muhalif bir çizgide olması, kendine yakın hissettiği siyasal aktörler hakkında olumsuz haberler üretmemesi bu yüzden de bazı hak arayışlarına dayalı eylemleri görmezden gelmesi dikkat çekicidir.

Hürriyet anaakım medyanın en güçlü gazetelerinden biri konumundadır. Gazete sivil ve siyasi haklar hakkında Cumhuriyet gazetesine oranla kısıtlı da olsa haber yapmış olsa bile sosyal hakların geliştirilmesi konusunda kayda değer bir haber üretememiştir. Toplumsal hareketlerle ilgili çok az sayıda haber üreten gazetede bazen grevler olumsuz bir dille verilmiştir. Örneğin THY hosteslerinin greviyle ilgili haberde, kurumun ve bu firmayı kullanan müşterilerin mağduriyeti ön plana çıkarmıştır. Kadının kamusal ve siyasal hayata katılımı, kadın cinayetleri ve kadın sorunları konusunda hassas bir gazete olduğunu vurgulasa ve hatta bunun için örgütlense de ele alınan beş buçuk senelik süreçte bu konuyu yapısal süreçte fazla ele almadığı gözlemlenmiştir. Gazetenin haberlerinin geneline bakıldığında, uzlaşmacı ve istikrarı destekleyici bireylerin makbul olduğu kanısı ortaya çıkmaktadır. Bu bireyler aynı zamanda liberal ekonomik politika çerçevesinde hareket etmelidir. 
Sonuç olarak ele alınan konu çerçevesinde incelenen iki gazetenin kendi ideolojik görüşleri çerçevesinde olayları gördükleri gözlemlenmektedir. Bu bağlamda Cumhuriyet Gazetesi, muhafazakâr/siyasal İslamcı güçlere muhalif, cumhuriyetin değerlerini savunan, toplumsal hareketlere katılan, kadının kamusal alan ve toplumdaki yerini olumlu yönde değiştirmeye çalışan haberleri idealize ederek okuyucusu olan vatandaşlara bu yönde telkinde bulunmuştur. Hürriyet gazetesi ise, modern, liberal demokrasiyi yücelten, çatışmacı/eleştirel düşünceden uzak haberleri ön plana çıkararak okuyucunun tutum ve değerlerinin bu yönde değişmesini sağlayacak söylemleri tercih etmiştir.

\section{Kaynakça}

Ahmad, F.(1999). Demokrasiye İlk Adım, Cumhuriyetin 75 Yılı (Cilt 1) 1923-1953, İstanbul: Yapı Kredi Yayınları.

Aybay, R. (1982). Yurttaşlık (Vatandaşlık) Hukuku Ders Kitabı ve Temel Yasa Metinleri, Ankara: Ankara Üniversitesi Siyasal Bilimler Fakültesi Yayınları.

Aybay, R. (1998). Teba-i Osmani'den T. C. Yurttaşına Geçişin Neresindeyiz?, 75 Yılda Tebaa'dan Yurttaş'a Doğru, A. Ünsal (Ed.), İstanbul: Tarih Vakfı Yayınları, s.37-42.

Barber, B. (1995). Güçlü Demokrasi Yeni Bir Çağ lçin Katıımcı Siyaset. (Çev. M. Beşikçi), İstanbul: Ayrıntı Yayınları.

Berkes, N. (2002). Türkiye'de Çağdaşlaşma, İstanbul: Yapı Kredi Yayınları.

Berktay, F.(2010). Politikanın Çağrısı, İstanbul: İstanbul Bilgi Üniversitesi Yayınları.

Bookchin, M. (1999). Kentsiz Kentleşme, Yurttaşığın Yükselişi ve Çöküşü, (Çev. B. Özyalçın), İstanbul: Ayrıntı Yayınları.

Caymaz, B.(2007). Türkiye'de Vatandaşılı Resmi İdeoloji ve Yansımaları, İstanbul: İstanbul Bilgi Üniversitesi Yayınları.

Cumhuriyetin 75 Yılı (1999) (Cilt 2) 1954-1978, İstanbul: Yapı Kredi Yayınları.

Fişek, H. (1959). Türk Vatandaşlık Hukuku, Ankara: Ankara Üniversitesi Hukuk Fakültesi Yayınları.

Gürses, F. (2011). Kul Tebaa Yurttaş Cumhuriyet'in Kuruluşundan Günümüze Ders Kitaplarında Yurttaşlık, Ankara: Ütopya Yayınevi.

Hall, S. ve Held, D.(1995). Yurttaşlar ve Yurttaşlık, S. Hall ve M. Jacques (Ed.), Yeni Zamanlar, 1990'larda Politikanın Değişen Çehresi, İstanbul: Ayrıntı Yayınları.

Heater, D.(2007). Yurttaş/ığın Kısa Tarihi (Çev. M. Delikara Üst), Ankara: İmge Kitabevi Yayınları.

Jorgensen, M. ve Phillips L.(2002), Discourse Analysis as Theory and Method, London: SAGE Publications.

Kadıoğlu A. (1999), Cumhuriyet Iradesi Demokrasi Muhakemesi Türkiye'de Demokratik Açılım Arayışları, İstanbul: Metis Yay. 
Leca, J. (1998). Bireycilik ve Yurttaşılık (Çev. T. Ilgaz), Turhan Ilgaz(ed.), Dersimiz: Yurttaşılı. İstanbul: Kesit Yayıncılık.

Leca, J.(1993). Yurttaşlık Üzerine Sorular. (Çev G. Koca). Birikim, Sayı: 55, Kasım, s.57-66.

Marshall, T. H. (2006). Yurttaşlık ve Toplumsal Sınıflar (Çev. A. Kaya), Yurttaşılk ve Toplumsal Sınıflar, H. Marshall ve T. Bottomore (ed), İstanbul: İstanbul Bilgi Üniversitesi Yayınları.

Mouffe, C. (1999). Yurttaşlık, Çoğulculuk ve Modern Demokrasi, Nuri Bilgin (ed.) Demokrasi, Kimlik ve Yurttaşlık Bağlamında Cumhuriyet, İzmir: Ege Üniversitesi Yayınları.

Schnapper, D.(1995). Yurttaşlar Cemaati Modern Ulus Fikrine Dair (Çev. Ö. Okur), İstanbul: Kesit Yayıncllık.

Tanilli, S. (1982). Devlet ve Demokrasi Anayasa Hukukuna Giriş, İstanbul: Say Kitap Pazarlama.

Tunçel, A. (2010). Bir Siyaset Felsefesi Cumhuriyetçi Özgürlük, İstanbul: İstanbul Bilgi Üniversitesi Yayınları.

Turner, B. S. (2008). Bir Vatandaşlık Kuramının Anahatları (Çev. C. Cemgil), Vatandaşlı̆ın Dönüşümü Üyelikten Haklara, Ayşe Kadıŏlu (ed.) İstanbul: Metis Yayınları.

Ünsal, A. (1998). Yurttaşlık Anlayışının Gelişimi, A. Ünsal (ed.), 75 Yılda Tebaa'dan Yurttaş'a Doğru, İstanbul: Tarih Vakfı Yayınları, s.4-37.

Ünsal, A. (1998). Yurttaşlık Zor Zanaat, A. Ünsal (ed.), 75 Yılda Tebaa'dan Yurttaş’a Doğru, İstanbul: Tarih Vakfı Yayınları, s.1-36

Üstel, F. (2008). Makbul Vatandaşın Peşinde II. Meşrutiyet’ten Bugüne Vatandaşlık Eğitimi, İstanbul: İletişim Yayınları.

Üstel, F. (1999). Yurttaşılı ve Demokrasi, Ankara: Dost Kitabevi Yayınları.

Walzer, M. (1995). Citizenship, T. Ball, J. Farr, Russell L. Hanson (ed.) Political Innovation and Conceptual Change, (Ed.), Cambridge: Cambridge University Press, s.211-219 